\title{
Republic of Slovenia: Financial System Stability Assessment
}

This paper was prepared based on the information available at the time it was completed on October 25, 2012. The views expressed in this document are those of the staff team and do not necessarily reflect the views of the government of the Republic of Slovenia or the Executive Board of the IMF.

The policy of publication of staff reports and other documents by the IMF allows for the deletion of market-sensitive information.

Copies of this report are available to the public from

International Monetary Fund • Publication Services

700 19th Street, N.W. • Washington, D.C. 20431

Telephone: (202) 623-7430 • Telefax: (202) 623-7201

E-mail: publications@imf.org • Internet: http://www.imf.org

\section{International Monetary Fund \\ Washington, D.C.}




\title{
INTERNATIONAL MONETARY FUND
}

\section{REPUBLIC OF SLOVENIA}

\section{Financial System Stability Assessment}

\author{
Prepared by the Monetary and Capital Markets and European Departments
}

Approved by José Viñals and Reza Moghadam

October 25, 2012

This Financial System Stability Assessment (FSSA) is based on the work of the Financial Sector Assessment Program (FSAP) mission that visited Slovenia in April 2012. The FSAP findings were discussed with the authorities during the Article IV Consultation mission in September 2012. The FSAP team comprised: Vassili Prokopenko (mission chief), Atilla Arda, Toshitake Inoue, Piyabha Kongsamut, Nada Oulidi, and Alejandro Simone (all IMF), as well as external experts Richard Britton, Bruno Estecahandy, Robert Kasinow, and Joel Shapiro. The FSAP team is thankful for the excellent cooperation it received from the authorities. Key conclusions:

- Slovenia's financial sector has been hard hit by the global financial crisis and remains vulnerable to continued credit deterioration and refinancing risks. Weak governance in public banks and an externally financed boom in lending to construction companies and management buyouts/corporate takeovers are at the root of the current problems.

- $\quad$ Several banks, including the largest ones, were recapitalized by the government, but further strengthening financial condition of banks should be the short term priority. The financial restructuring should be followed by bank privatization.

- While the regulatory and supervisory frameworks are broadly in line with international standards, some specific weaknesses exist, especially in supervising state-owned banks. The crisis preparedness and management framework needs significant strengthening.

The main author of this report is Vassili Prokopenko with contributions from the rest of the FSAP team.

FSAP assessments are designed to assess the stability of the financial system as a whole and not that of individual institutions. They have been developed to help countries identify and remedy weaknesses in their financial sector structure, thereby enhancing their resilience to macroeconomic shocks and cross-border contagion. FSAP assessments do not cover risks that are specific to individual institutions such as asset quality, operational or legal risks, or fraud. 
Glossary 4

Executive Summary ........ .5

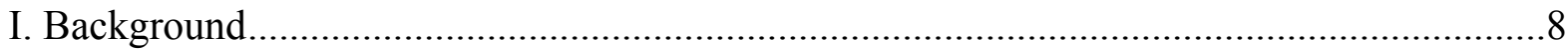

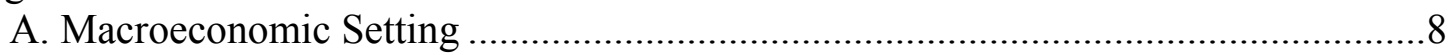

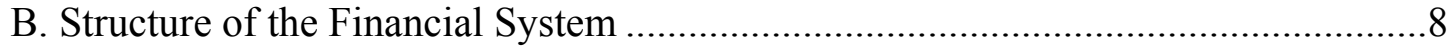

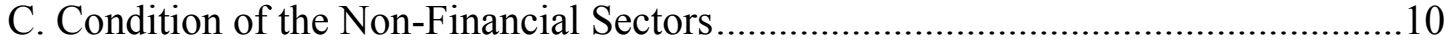

II. Key Risks and Challenges in the Financial Sector...................................................... 11

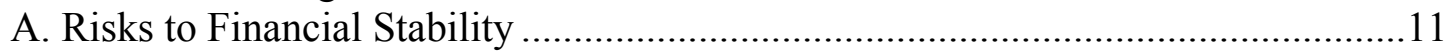

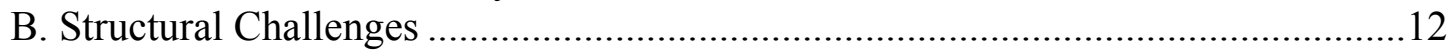

III. Strengths and Vulnerabilities: Institutions and Markets ............................................. 14

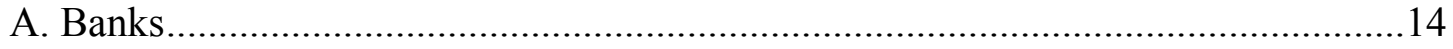

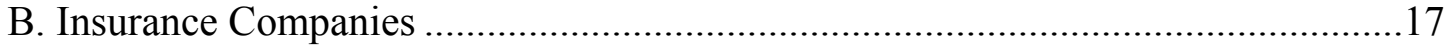

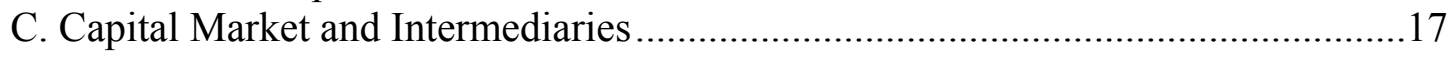

IV. Strengths and Vulnerabilities: The Policy Framework................................................. 18

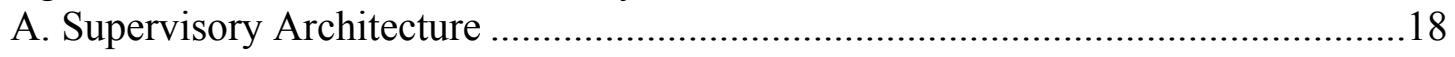

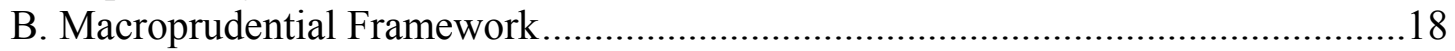

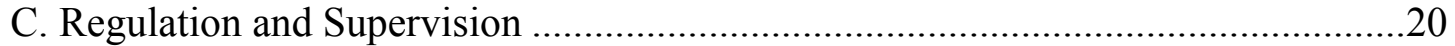

D. Crisis Management and Safety Nets ..........................................................23

E. Anti-Money Laundering and Combating Financing of Terrorism (AML/CFT) .....25

Tables

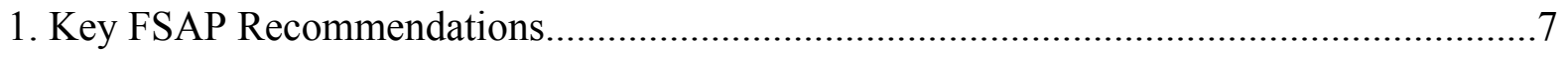

2. Selected Macroeconomic Indicators 2008-2014 ...........................................................27

3. Structure of the Financial System 2006-2011 ...........................................................28

4. Financial Soundness Indicators by Banking Group, 2008-11 .......................................29

5. Stress Testing Macroeconomic Scenarios, 2012-13 .....................................................30

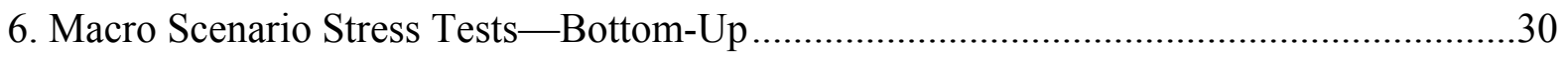

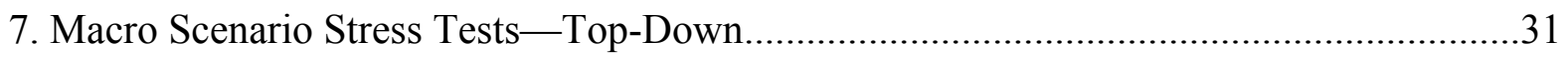

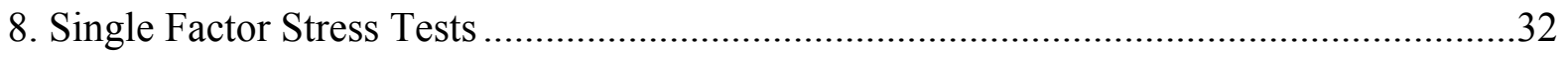

Figure

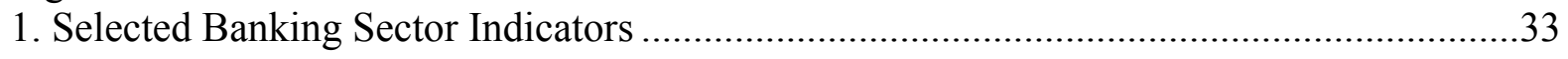

Box

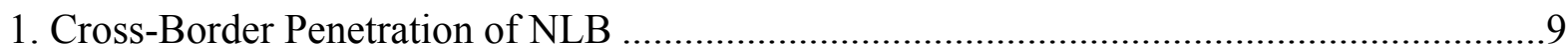




\section{Appendixes}

I. Status of the Main Recommendations of the 2003 FSAP

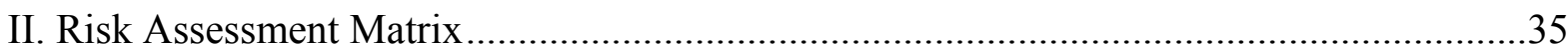

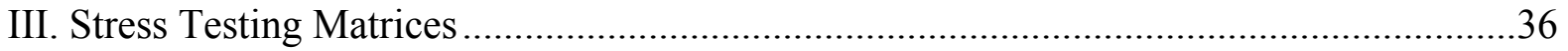

Appendix Tables

1. Summary Compliance with the Basel Core Principles

2. Recommended Action Plan to Improve Compliance with the Basel Core Principles

Annex I. Summary Observance of the Basel Core Principles for Effective Banking

Supervision .38

A. Information and Methodology Used for the Assessment....................................38

B. Institutional and Macro-Prudential Setting and Market Structure ..........................38

C. Preconditions for Effective Banking Supervision .............................................39

D. Main Findings 


\section{GLOSSARY}

$\begin{array}{ll}\text { ACH } & \text { Automated Clearing House } \\ \text { AMC } & \text { Asset Management Company } \\ \text { AML/CFT } & \text { Anti-Money Laundering and Combating the Financing of Terrorism } \\ \text { ATVP } & \text { Securities Market Regulatory Agency } \\ \text { AZN } & \text { Insurance Supervisory Agency } \\ \text { BCP } & \text { Basel Core Principles } \\ \text { BOS } & \text { Bank of Slovenia } \\ \text { BSD } & \text { Banking Supervision Department } \\ \text { CAR } & \text { Capital Adequacy Ratio } \\ \text { COPER } & \text { Common Repository } \\ \text { CPSS } & \text { Committee on Payment and Settlement Systems } \\ \text { DGS } & \text { Deposit Guarantee Scheme } \\ \text { EBA } & \text { European Banking Authority } \\ \text { ECB } & \text { European Central Bank } \\ \text { EDF } & \text { Expected Default Frequency } \\ \text { ELA } & \text { Emergency Liquidity Assistance } \\ \text { FATF } & \text { Financial Action Task Force } \\ \text { FSAP } & \text { Financial Sector Assessment Program } \\ \text { FSB } & \text { Financial Stability Board } \\ \text { FSC } & \text { Financial Stability Committee } \\ \text { GAAP } & \text { Generally Accepted Accounting Principles } \\ \text { IAIS } & \text { International Association of Insurance Supervisors } \\ \text { ICP } & \text { Insurance Core Principles } \\ \text { IFRS } & \text { International Financial Reporting Standards } \\ \text { IOSCO } & \text { International Organization of Securities Commission } \\ \text { IRB } & \text { Internal Ratings-Based } \\ \text { LTRO } & \text { Long Term Refinancing Operations } \\ \text { MOF } & \text { Ministry of Finance } \\ \text { MOU } & \text { Memorandum of Understanding } \\ \text { NBFI } & \text { Non-Bank Financial Institution } \\ \text { NPL } & \text { Nonperforming Loans } \\ \text { OR } & \text { Operational Risk } \\ \text { RAS } & \text { Risk Assessment System } \\ & \end{array}$




\section{EXECUTIVE SUMMARY}

The Slovenian financial system has been hard hit by the crisis. Weak governance in public banks and a credit boom financed externally and directed in significant part towards construction companies and management buyouts/corporate takeovers are at the root of the problems. As a result of a significant deterioration in credit quality, the banking sector has reported operating losses for the last two years. The government had to step in with capital injections in some of the largest state-controlled banks. The deleveraging process that began in 2009 is proving to be protracted.

Banks remain highly vulnerable to continued credit deterioration and refinancing risks. The corporate sector is over-indebted and suffers from the double-dip recession. Based on the end-2011 data, stress test results show that under a double-dip adverse scenario, the capitalization of the banking system would fall below the prudential minimum, and a recapitalization in the amount of around 5 percent of GDP would be needed to bring the system core Tier I capital ratio to 9 percent. The exposure to real estate price risk is particularly significant, reflecting the high share of loans backed by real estate collateral. A further sovereign downgrade would seriously impair the government's ability to recapitalize the troubled banks, though the recent successful bond issuance reduce this risk in the short term.

\section{Strengthening the financial condition of banks should be the short-term priority.} Although the European Central Bank (ECB)'s 3-year Long Term Refinancing Operations (LTRO) have reduced the immediate liquidity pressures, a structural adjustment in the balance sheets is needed for banks to become less dependent on wholesale or the Eurosystem's financing. A stronger bank capitalization would reduce downward pressure on the sovereign rating, and help avoid disorderly deleveraging by allowing banks to make new loans. At the same time, banks should restructure their balance sheets by fully recognizing problem loans and writing off bad loans. The authorities are undertaking a comprehensive review of banks' asset portfolios, with third-party participation. This is a welcome step and should provide the basis for determining further restructuring needs. The asset management company, which is currently in the process of being established, may help address the overhang of bad debt.

\section{The financial restructuring should be followed by privatization of the state-controlled} banks. The privatization would help address the long-standing governance weaknesses of these banks, which were put into the spotlight by the crisis. Reducing government influence on the day-to-day operations and lending decisions of banks will help improve the risk management practices and the efficiency and stability of the banking system over the longer term. 
The assessment of the regulatory and supervisory frameworks identifies both strengths and weaknesses. Specifically:

- Banking supervision. The assessment of the Basel Core Principles for Effective Banking Supervision noted improvement since the previous 2003 assessment. However, the BOS's powers should be strengthened in several areas, including in the licensing or removal of bank supervisory board members, and requiring banks to obtain authorization for acquiring non-bank financial companies. In addition, the bank shareholders' discretion to impede BOS's requirement to increase capital must be resolved, and legal protection for bank supervisors should be strengthened. The reporting of problem assets lacks granularity, and the provisioning on NPLs seems relatively low.

- Insurance supervision. The insurance regulator (AZN) has an effective system of both on-site and off-site monitoring. Although the agency has adequate staff resources, its compensation policies need to be more market-oriented in order to keep and attract talented staff. The implementation of Solvency II regulation in 2014 will be a major challenge for AZN, which further underscores the need for adequate staff and expertise.

- $\quad$ Securities market regulation. The securities market regulator (ATVP) generally follows best international practices. It appears to have sufficient resources to meet its operational responsibilities, although its compensation scheme-similarly to the case of AZN — should be adjusted to ensure staff retention and attraction. There is room to further strengthen its independence, broaden its sanctioning powers, and improve the transparency of its internal processes.

The supervision of financial institutions should be complemented with a macroprudential overview geared towards overall stability of the financial system. Although BOS has well-developed tools for detecting and monitoring systemic financial sector risks, and many policy instruments to contain systemic risks have been deployed in recent years, a fully-fledged macro-prudential mandate is not enshrined in the existing legislation.

The crisis preparedness and management framework needs significant improvement. The BOS's powers to deal with a failing bank need to be substantially expanded or clarified to ensure that a bank resolution is done effectively on a least-cost basis. Major changes to the design of the deposit guarantee scheme (DGS) are needed, converting DGS from an ex-post pay-box entity into an active tool in bank resolution by empowering the DGS to apply its funds for the purposes of bank resolution. The framework for official liquidity and solvency support by the government also needs to be strengthened.

The key recommendations of the mission are prioritized in Table 1, and the status of implementation of the recommendations of the previous FSAP is shown in Appendix I. 
Table 1. Slovenia: Key FSAP Recommendations

\begin{tabular}{|c|c|c|}
\hline & Recommendations & $\begin{array}{l}\text { Paragraph } \\
\text { reference }\end{array}$ \\
\hline \multicolumn{3}{|c|}{ Priority (Immediate implementation) } \\
\hline & $\begin{array}{l}\text { Proceed with the establishment of an asset management company, ensuring } \\
\text { its adequate powers, resources, accountability, and other operational aspects } \\
\text { (Ministry of Finance, MOF) }\end{array}$ & 16 \\
\hline & $\begin{array}{l}\text { Ensure recapitalization of state-owned banks and strengthen their governance } \\
\text { (MOF) }\end{array}$ & $16,17,19$ \\
\hline & Strengthen legal framework for bank resolution (BOS) & 51 \\
\hline & Establish operational crisis management arrangements (BOS, MOF) & 54 \\
\hline \multicolumn{3}{|c|}{ Short-term (Implementation within 12 months) } \\
\hline & Eliminate the special tax on banks (MOF) & 36 \\
\hline & $\begin{array}{l}\text { Expand each supervisory agency's mandate to include macro-prudential } \\
\text { oversight and assign BOS to play a leading role in systemic risk assessment }\end{array}$ & 38,39 \\
\hline & Strengthen risk assessment and management in banks (BOS) & 41 \\
\hline & Ensure adequate legal protection for bank supervisors (BOS) & 43 \\
\hline & $\begin{array}{l}\text { Require banks to obtain authorization prior to acquiring a non-bank financial } \\
\text { company (BOS) }\end{array}$ & 43 \\
\hline & $\begin{array}{l}\text { Ensure that ATVP and AZN are not subject to the Public Agencies Act, Public } \\
\text { Sector Wage System Act, and Civil Servants Act (the latter with respect to the } \\
\text { regulation of wages and rewarding of employees) }\end{array}$ & 46,49 \\
\hline & $\begin{array}{l}\text { Extend the ATVP's fining power under the Minor Offences Act to banks } \\
\text { carrying on investment activities or providing investment services }\end{array}$ & \\
\hline & Redesign DGS to allow funding bank resolution (BOS) & 52 \\
\hline & Strengthen legal framework for official financial support (BOS/MOF) & 53 \\
\hline \multicolumn{3}{|c|}{ Medium-term (Implementation in 1-3 years) } \\
\hline & $\begin{array}{l}\text { Encourage banks to reduce dependence on external and wholesale } \\
\text { borrowings (BOS) }\end{array}$ & $13,14,20$ \\
\hline & Reduce government ownership in financial institutions (MOF) & 17,44 \\
\hline & Expand BOS's supervisory resources, especially the off-site staff & 42 \\
\hline & $\begin{array}{l}\text { Continually monitor Solvency II developments that will require changes to } \\
\text { current legislation and information systems, and ensure that adequate staffing } \\
\text { and expertise are available (AZN) }\end{array}$ & 47 \\
\hline
\end{tabular}




\section{BACKGROUND}

\section{A. Macroeconomic Setting}

1. Slovenia, a Euro-zone member country since January 2007, was hard hit by the global financial crisis of 2008-09 (Table 2). During the pre-crisis years, rapid GDP growth reflected strong domestic demand financed by bank borrowing and exports. An abrupt deterioration in macroeconomic and financial conditions in the euro area led to a sharp fall in exports and external funding for the banking system dried up. As a result, real GDP experienced one of the largest falls in the Euro area (a decline of about 10 percent from peak to trough).

2. The economy started to recover in 2010, but the escalation of the euro area crisis in the second half of $\mathbf{2 0 1 1}$ interrupted the recovery. The deterioration in construction activity and net exports led GDP growth to fall by 0.2 percent in 2011 after growth of 1.4 percent in 2010 . The recession intensified in 2012, as euro area growth decelerated and domestic consumption declined. Unemployment almost doubled since 2008 to 8.4 percent in August 2012. Despite a structural fiscal contraction, the general government deficit on a cash basis increased from 5.4 percent of GDP in 2010 to 5.7 percent of GDP in 2011.

\section{B. Structure of the Financial System}

3. Total assets of Slovenia's financial institutions stood at $€ 65$ billion by end 2011 (Table 3). This was equivalent to 182 percent of GDP or about a third of the average Euro area country. Financial depth in Slovenia had been increasing steadily since the Euro adoption, but was slowed by the financial crisis. Banks remain the most important financial institutions in Slovenia, but insurers, leasing companies, and other institutions made up a quarter of the system.

4. State-owned financial institutions dominate the system. The lead companies in the three major financial groups (NLB, NKBM, and Triglav) are all at least 50 percent directly or indirectly controlled by the government. State-controlled banks account for around 55 percent of the system in terms of assets or capital. Consequently, Slovenia has one of the lowest market shares of foreign banks among all Eastern European countries (30 percent of the total). Nevertheless, the international banking groups from Austria, Italy, France, and a few other countries have a stake in most of the ten largest Slovenian banks, including the minority stake of Belgium's KBC in NLB. NLB has a substantial presence in several foreign markets (Box 1). ${ }^{1}$

\footnotetext{
${ }^{1}$ The second largest bank, NKBM, also has a presence abroad albeit very small.
} 


\section{Box 1. Cross-Border Penetration of NLB}

The largest Slovenian financial institution, NLB Group, has a substantial presence abroad, especially in the countries of the former Yugoslavia. Banking is the group's most important activity, and the NLB subsidiaries rank among the largest five banks in Bosnia, Kosovo, Macedonia, and Montenegro (Table). The group also has several relatively small non-bank financial institutions abroad (also mainly in the former Yugoslavia), including leasing and factoring companies.

Table. NLB Banking Activities in the Ex-Yugoslavia

\begin{tabular}{lrrr}
\hline & $\begin{array}{r}\text { Assets } \\
(€ \mathrm{~m})\end{array}$ & $\begin{array}{r}\text { Market share } \\
\text { (in \%) }\end{array}$ & Market rank \\
\hline Bosnia (Republika Srbska) & 579 & 20 & 2 \\
Bosnia (Federation of Bosnia and Herzegovina) & 459 & 6 & 5 \\
Kosovo & 386 & 15 & 3 \\
Macedonia & 992 & 19 & 3 \\
Montenegro & 529 & 19 & 2 \\
Serbia & 421 & 2 & 16 \\
Slovenia & 12,980 & 27 & 1 \\
Total NLB Group & 16,445 & & \\
\hline
\end{tabular}

Source: NLB 2011 Annual Report

The performance of foreign entities in the NLB group has been mixed. The operating results of bank subsidiaries have remained broadly satisfactory, with moderate profits in 2011 . The performance of non-bank financial subsidiaries, especially factoring companies, has been disappointing, with substantial losses in 2011. These losses reflect weak internal controls and risk management practices in these subsidiaries, as well as the effects of the macroeconomic slowdown in the region.

In 2010, NLB adopted a restructuring strategy that includes the divestment of non-core foreign financial subsidiaries. The strategy, which was agreed with the EC under State Aid rules, defines strategic markets and activities of the NLB group. The strategic markets include certain countries of the former Yugoslavia, while the strategic activities are focused on the banking services. In line with this strategy, NLB has begun selling off or closing down its foreign entities (for example, a factoring company in Slovakia was closed in 2010 and a bank subsidiary in Bulgaria was sold in 2011). 


\section{Bank exposures to non-bank financial institutions (NBFIs) are small but some} NBFIs have considerable exposure to banks. While the largest banks have interests in insurance companies, pension funds, investment funds, and leasing companies, those interests are small in relation to the size of the banking system. On an aggregate basis, only 4.4 percent of bank assets are exposed to other financial intermediaries. On the other hand, insurance companies and pension funds have 23 percent of their assets in the form of bank bonds, bank deposits, and (to a lesser extent) bank equity. There are two financial conglomerates centered on the insurance companies.

\section{Condition of the Non-Financial Sectors}

\section{The Corporate Sector}

6. The corporate sector has been substantially affected by the financial crisis of 2008-09. After building up the debt-to-GDP ratio to almost 170 percent in 2008, one of the highest levels among the Euro area countries, during the period of abundant credit and declining interest rates, the Slovenian corporate sector faced plummeting domestic and external demand. This resulted in financial difficulties and associated increases in payment indiscipline and corporate bankruptcies. The tightening in financing conditions forced the corporate sector to deleverage. Non-export-oriented corporates were especially affected since, unlike export-oriented corporates, they have not been able to partially substitute the fall in local bank financing with direct financing from the rest of the world.

\section{The construction sector has been the worst affected and is unlikely to have} bottomed out yet. As credit dried up, residential and commercial real estate construction slowed substantially as illustrated by a declining liquidity in the real estate market. The real estate market decline also coincided with the end of large construction projects in 2008-2009. As a result of this combination of factors, payment arrears of construction companies increased, and two large Slovenian construction companies went bankrupt in 2011.

\section{The Household Sector}

8. The balance sheet of the household sector is relatively strong. In 2010, household assets excluding real estate (113 percent of GDP) exceeded total household liabilities (35 percent of GDP) by a large margin, and were relatively liquid, with slightly over 50 percent in cash or bank deposits. ${ }^{2}$ Household liabilities are mostly consumer and mortgage loans from banks with an average maturity exceeding 15 years, and the average loan-to-value ratio for housing loans is around 60 percent. The debt-to-disposable income ratio stood at 53 percent in 2010 (compared to close to 100 percent in the Euro area).

\footnotetext{
${ }^{2}$ The data on household assets invested in real estate are not available.
} 
9. Notwithstanding the overall situation, there may be pockets of weakness, especially among the lowest income households. The 2009 recession and the subsequent weak recovery have led to a significant slowdown in the growth of disposable income. This contributed to a weakening consumer confidence and a growing uncertainty about income prospects. As a result, the demand for mortgage loans declined substantially in 2011, from the rapid rates recorded earlier. Nonperforming loans - which until now stand at a relatively low level (3.5 percent of total household loans at end-2011) — may still increase, especially given the decline in equity and real estate prices.

\section{Key Risks ANd Challenges in the FinanCial SeCtoR}

\section{A. Risks to Financial Stability}

\section{Risks to systemic financial stability are significant (Risk Assessment Matrix,} Appendix II). These risks arise mainly from the negative macroeconomic outlook for Slovenia and its trading partners, and the still high dependence of Slovenian banks on external funding. The deleveraging process affecting banks and corporates, which began in 2009 , is proving to be protracted.

11. As the baseline now encompasses a double-dip recession, credit risk represents the major vulnerability for banks. Credit risk can materialize via multiple channels, including through (i) stagnant or shrinking export markets feeding through to the manufacturing sector; (ii) weak consumer demand associated with increasing levels of unemployment; and (iii) delays in the improvement in the financial position of corporates. The rapid pre-crisis increase in credit to the corporate and household sectors often reflected lax credit origination standards, which may be further exposed as the economy worsens.

12. The real estate price risk is of particular concern. Residential and commercial real estate prices increased by 40-50 percent from 2005 to 2008, but this trend was subsequently interrupted by the crisis, and a downward price correction has been under way since 2009 . Real estate prices have fallen by around 10 percent since the peak in 2008 , reflecting tighter lending standards and reduced demand.

\section{Refinancing risk is another important risk to which Slovenian banks are} exposed, due to the still significant reliance on wholesale funding. Like in many other countries, funding issues were not given sufficient attention either by banks or the supervisor ahead of the crisis. The Slovenian banks became heavily reliant on external borrowings in the wholesale market, with the aggregate loan-to-deposit ratio climbing to over 160 percent in 2008. The downgrades of the Slovenia's sovereign rating led to a cut in the ratings of several 
domestic banks. ${ }^{3}$ Commercial funding has practically dried up for the Slovenian banks (with the exception of parent funding of their local subsidiaries), and banks repaid external creditors almost $€ 6$ billion since 2008 ( 16 percent of GDP). At the same time, the expectation of a further increase in NPLs puts downward pressure on the sovereign rating.

14. The ECB's 3-year LTROs have reduced the immediate liquidity and refinancing risks, particularly for government-controlled banks, but the balance sheet adjustment has some way to go. Besides the LTROs and other bank refinancing already secured in the first quarter of 2012, the banking system holds additional collateral that provides a buffer in case of further sovereign downgrades and associated haircuts, or can be used for possible further ECB refinancing. However, some individual banks do not have much eligible collateral, which is a source of concern. Also, the system's loan-to-deposit ratio still remains high, banks still need to further reduce their reliance on short-term wholesale and Eurosystem financing, access to fresh capital is difficult, and there remains a significant risk of a sharp deleveraging. At the same time, it should be noted that ongoing deleveraging of non-core assets and in non-core subsidiaries can stabilize funding markets, decrease common exposures, and —in turn — contribute to a lower systemic risk.

\section{Other immediate risks facing the Slovenian banks are of a lesser magnitude.}

Market risk is small as market activities for the banks are limited and receding. Country and transfer risks are almost negligible as 89 percent of Slovenian banks' non-consolidated credit exposure is to domestic debtors, and there is no material exposure to non-residents. The exposure to the EU peripheral countries (Greece, Ireland, Italy, Portugal, and Spain) is very small, and most of the exposure to the rest of the world is in the form of government securities of the core Euro-zone countries. Interest rate risk on the banking book is also relatively small as a large portion of loans to corporates and households, including mortgages, are granted with variable rates while most liabilities are indexed to interbank borrowing indices.

\section{B. Structural Challenges}

16. There is a need to address important structural challenges. To restore the banking system's profitability and its ability to support sustained economic growth, the following actions should be taken:

- Determination of the bank restructuring needs. The authorities have initiated a comprehensive review of asset portfolios of the largest government-controlled banks, with third party participation. The review by an independent firm should provide the

\footnotetext{
${ }^{3}$ Fitch, Moody's, and S\&P downgraded Slovenia one notch to AA-, Aa3, and AA- respectively in September 2011. This was the first change in the sovereign rating of Slovenia by these three agencies since 2005. Since then, all three agencies further downgraded Slovenia.
} 
basis for a comprehensive clean-up of the system, enhancing market confidence. Such a due diligence exercise has already been completed for the two largest banks and is currently under way for the third largest bank. Based on this exercise, the government estimates that action is needed to manage impaired assets of up to $€ 3$ billion.

- $\quad$ Cleaning up bank balance sheets. Several options to manage impaired assets can be considered including the establishment of special loan work-out units or the transfer of assets to a separate asset management company (AMC). All the largest banks established loan work-out units in the past year or so, but without evident success. In early October 2012, the authorities decided to set up an AMC. The intention is to allow the AMC to issue up to $€ 4$ billion of government-guaranteed loans, and to acquire impaired assets at their "real long-term value," following the EC State Aide Guidelines. The AMC will be wound down after five years, at which point the remaining assets will be transferred to the Slovenia Sovereign Holding company. The AMC may bring benefits since it would enhance banks' liquidity position and can also result in economies of scale in managing the bad assets. However, such an entity would need to be carefully designed in order to avoid creating incentives for further rounds of similar bank cleansing. The experience of other countries suggests that a successful AMC should have a clear objective, be independent from political interference, have adequate legal and funding resources, and remain accountable for its activities. The AMC should also largely dispose its assets by the date of its termination in order to reduce the risk of continued state interference in the corporate sector, and the disposition of any residual assets transferred to the Sovereign Holding company should be done without undue delays.

- Bank recapitalization. Bank recapitalization will be necessary in the process of loss recognition, including in the process of transferring some assets to the AMC at prices below book value. Some additional capital margin would also be needed in order to absorb any further losses related to the economic downturn as well as to support lending.

- $\quad$ Corporate balance sheet adjustment. The corporate sector is highly leveraged and needs to reduce its reliance on bank funding, preferably through new sources of equity. This is especially true for the construction sector. Given the lengthy corporate bankruptcy process, the AMC should be actively involved in the financial restructuring of the corporate sector and informal corporate debt workout mechanisms should be explored.

\section{Reforming state-controlled banks would also help revitalize the banking sector.}

The performance of state-controlled banks has been consistently weaker than that of any other groups of banks in the last three years. For example, return on assets for the large domestic banks (of which four state-owned banks account for 80 percent of this group's market share) was zero in 2009 and worsened to -1.3 percent in 2011, which was a much 
worse outcome than that for other groups of banks, particularly foreign banks (Table 4). Return on equity showed similar trends. The privatization of state-controlled banks would help address the long-standing weaknesses in the governance and risk management practices of these banks, which were put into the spotlight by the crisis. Leaving the situation unchanged would result in a continued misallocation of resources and repeated recapitalization needs.

\section{STRENGTHS AND VULNERABILITIES: InSTITUTIONS AND MARKETS}

\section{A. Banks}

\section{Performance}

18. The performance of banks deteriorated markedly in recent years (Table 4 and

Figure 1). The non-performing loan (NPL) ratio of the banking sector was 11.9 percent in 2011 and increased further to 12.6 percent by June 2012, driven essentially by loans to construction companies and loans to management buy-outs in various sectors. As a result, the operating profits - which were already affected by reduced lending and increased funding costs - were wiped out and banks have registered substantial losses since 2010. Total bank losses (on a consolidated basis) amounted to $€ 508$ million in 2011 (up from $€ 120$ million in 2010), and banks continued to report losses in the first half of 2012.

\section{Although capital adequacy improved in 2011, many banks need to further} increase capital. The aggregate capital adequacy ratio (CAR) stood at 12 percent as of December 2011, up from 11.3 percent in 2010. The improvement was partly attributed to fresh capital injections in six banks totaling $€ 458$ million. ${ }^{4}$ It also reflected a decline in riskweighted assets through deleveraging and divestments of non-core activities and subsidiaries of banks. However, banks' continuing losses erode their excess in regulatory capital. As of end-2011, 12 banks fell short of the Core Tier I ratio of 9 percent (a benchmark recommended by EBA using the definition of capital which is neither Basel II nor CRD but a hybrid approach developed by the EBA), with a total shortfall of $€ 540$ million. As a result of EBA requirements, the largest Slovenian bank, NLB, was required to raise $€ 320$ million in additional capital by June $2012 .{ }^{5}$ In the event, NLB was recapitalized by $€ 383$ million, but further recapitalization may be needed given the current weak economic environment and/or the transfer of some loans to the asset management company at the below book values. ${ }^{6}$ If

\footnotetext{
${ }^{4}$ Most of this amount was the injection of government funds in two largest banks: in 2011, NLB and NKBM were recapitalized for a total of $€ 250$ million and $€ 101$ million respectively.

${ }^{5}$ The largest two banks were included in the EBA stress tests. Both passed the June 2011 tests, but the NLB was found to have a capital shortfall in the December 2011 tests.

${ }^{6}$ As approved on a temporary basis by the European Commission in early July 2012, NLB was recapitalized through $€ 320$ million of contingent convertible instruments and an injection of $€ 63$ million in common equity.
} 
efforts to find private investors prove unsuccessful, the government will end up recapitalizing the bank again, extending the pressure on public finances.

\section{The short-term liquidity ratios appear adequate but may mask longer-term}

structural imbalances. The first bucket liquidity ratio (the ratio of financial assets to financial liabilities with residual maturity of up to 30 days) stood at 140 percent and the ratio of liquid assets to short-term liabilities was 40 percent at end-2011. However, liquidity ratios of foreign banks are less comfortable. Although their access to parent bank credit lines provides some reassurance, such access hinges on the parent bank's ability and willingness to support the subsidiary. The loan-to-deposit ratio for the system as a whole (which stands at 135 percent) signals that banks' reliance on wholesale funding is excessive. The reported maturity of wholesale funding is relatively long, and there are no major bank refinancing needs within the next year or so. However, in case of further sovereign downgrade, some loans to Slovenian banks may come immediately due. Moreover, government deposits, which account for about $€ 2$ billion, are declining as government draws funds to finance the fiscal deficit.

\section{Bank balance sheets contracted in 2011 and continue to contract in 2012,} reflecting deleveraging and divestment of non-core activities. Credit to the corporate sector declined by 6.2 percent, reflecting both demand and supply factors. While credit fell to most corporate sectors, exposures to the ailing construction sector increased as a result of loan restructuring that involved a capitalization of interest payments. Strains in wholesale funding markets, following Slovenian sovereign and bank downgrades, reduced credit supply. A growing number of corporate bankruptcies also contributed to banks' increased risk aversion.

\section{Stress tests}

\section{Assumptions}

\section{A range of stress tests were carried out in the context of the FSAP}

(Appendix III). The assumptions of the tests were designed jointly by the BOS and the FSAP team. The top-down tests were carried out by the BOS, and the bottom-up tests were performed by individual banks. The tests covered all banks operating in Slovenia both on consolidated and solo basis as of December 2011, and considered credit, sovereign, market, and liquidity risk factors.

23. Macro stress tests considered three scenarios spanning two years (2012-13). The tests covered (i) the direct credit losses from deteriorating quality of loans and off-balance sheet commitments, (ii) an increase in bond spreads and subsequent mark-to-market losses 
from sovereign bond holdings, and (iii) the effects of stressed funding costs. The tests assumed a zero growth in bank balance sheets. The scenarios included: ${ }^{7}$

- A baseline scenario (a double-dip scenario) in line with the latest BOS projections, which were finalized and published during the FSAP mission. The projections were slightly more severe than the WEO projections for GDP growth at the time of the mission.

- A double-dip adverse scenario simulating a worsening of the Euro area crisis in line with that observed in 2008-09. This included a decline in exports, negatively affecting growth, labor market, investment, and consumption, and the increase in the Euribor rates by 200 basis points. The strains in the wholesale funding markets and worsening asset quality were assumed to squeeze banks' operating profits. In addition, a widening of Euro area sovereign spreads was assumed to lead to bank marked-tomarket losses from sovereign bond holdings. A weak recovery was assumed in 2013.

- A slow-growth scenario simulating a lengthier recession in the Euro-zone resulting in a prolonged low growth in Slovenian exports and a dearth of investment opportunities. This scenario assumed a similar shock to sovereign spreads as in the double-dip adverse scenario. The Euribor rate was assumed to increase somewhat less than in the double-dip adverse scenario (by 100 basis points), reflecting the less acute nature of the shocks in this scenario.

24. Several single-factor stress tests were also considered. These included: (i) tests for a real estate market price shock (assuming a decline in commercial and residential real estate prices by 25 percent and 15 percent respectively); (ii) tests for concentration risk (assuming a deterioration in the quality of the three largest exposures of each bank); and (iii) tests for refinancing risk (assuming a reduction in the wholesale external funding of banks). ${ }^{8}$

\footnotetext{
${ }^{7}$ See Table 5 for details. The top-down stress tests considered all three scenarios, while the bottom-up tests included only the baseline and double dip adverse scenarios.

${ }^{8}$ The bottom-up tests for refinancing risk assumed a partial roll-over of maturing foreign loans (only 20 percent for domestically-owned banks and 40 percent for foreign-owned banks, reflecting the higher access of foreign banks to international capital markets) and a one notch downgrade of Slovenia's sovereign rating (leading to a decline in eligible collateral for ECB financing). The tests aimed to evaluate the deficit (if any) in eligible collateral, as the liquidity shortage was assumed to be financed by the ECB funding. The stress tests spanned two years (2012-13) during which loans were assumed to remain constant. The top-down tests for refinancing risk assumed a zero roll over in the maturing wholesale funding, and the impact was assessed on the necessary deleveraging by banks in the form of reduced loans and interest income.
} 


\section{Results}

25. The results of macro scenario stress test highlight the vulnerabilities of banks. Even under the baseline scenario, the CAR of several banks would fall below the required minimum of 8 percent in 2013, with a total capital shortfall of $€ 60$ million (Table 6). Under the double-dip adverse scenario, the CAR shortfall would be $€ 518$ million, with the greatest shortfall seen in the large domestic banks. Many banks would end up with Core Tier I ratio below 9 percent, with a total shortfall of $€ 1.9$ billion (around 5 percent of GDP). The results of top-down stress tests are broadly consistent with those of the bottom-up tests (Table 7).

\section{Single factor stress tests reveal a high vulnerability to real estate price risk}

(Table 8). This reflects a high share of loans in bank portfolios backed by real estate as collateral. The impact of real estate price shock is highest for the large banks. Banks are also exposed to concentration risk (as indicated by the results of large exposure stress tests) and refinancing risk. Large domestic banks and foreign banks are the most affected by the refinancing risk, reflecting a high reliance of these banks on short-term wholesale funding.

27. Important caveats should be attached to these FSAP stress test results. As with any stress testing exercise, this analysis does not adequately capture the feedback between banking system performance and macroeconomic performance. These feedbacks are especially important in periods of severe financial turmoil, akin to the one experienced in Slovenia. In addition, the recent government's estimates in relation to the establishment of the AMC (authorized to issue bonds of up to $€ 4$ billion) may raise doubts about the quality of reported loan provisions and/or collateral valuation, possibly resulting in some overestimation of the baseline capital position of banks.

\section{B. Insurance Companies}

28. The performance of the insurance sector is satisfactory. All insurance companies were solvent as of end-2011, and all but one is profitable in a market made up of 16 insurers and two reinsurers. The market is 75 percent written by Slovenian companies, and all available distribution channels are utilized including exclusive and independent agents, banks, internet, and direct sales. The non-life market remains highly competitive in comparison to life business. Motor vehicle liability and motor vehicle land motor are the dominant classes in non-life accounting for almost 55 percent of total non-life premium. The largest life products (in terms of premium) are linked to investment fund units (approximately 48 percent).

\section{Capital Market and Intermediaries}

29. The capital market (which is small) has not recovered from the global financial

crisis. Between the peak levels of August 2007 and October 2012, the Blue Chip index of the Ljubljana Stock Exchange (LSE) fell by almost 80 percent mainly due to the weak macroeconomic performance and the massive seizure of equities by the banks as collateral 
under the management buyout loans. Many foreign investors have left the market. The decline in liquidity since 2007 has acted as a constraint on further foreign investment as it also made planning an exit strategy almost impossible. This is reflected in the declining level of activity and hence broker profitability.

30. The LSE is part of an expanding Central and Eastern European Stock Exchange Group (CEESEG), which insulates it in the short term from pressures related to the decline in income. However, its trading volume is less than 1 percent of the total for the group. If there is no recovery in the Slovenian market in the medium term, CEESEG's controlling shareholders may consider it more profitable to concentrate trading in Slovenian stocks on the Vienna Exchange (both exchanges share the same trading system). In practice, it appears that listed companies are already moving out, in particular to the Warsaw Stock Exchange.

\section{Strengths ANd Vulnerabilities: The Policy Framework}

\section{A. Supervisory Architecture}

31. There has been extended domestic discussion on reform of the supervisory architecture, with different models under consideration. These models range from the status quo (there are three separate supervisory agencies at present: BOS, AZN, and ATVP, which are in charge of respectively banks, insurance companies, and securities markets) to a fully integrated supervision within BOS.

32. In general, the team cautioned against any changes to the supervisory architecture at the present time given the other challenges being faced. The banking system requires intensive efforts to restore its soundness and profitability and BOS is preparing for implementation of Basel III. AZN is preparing for transition to Solvency II. ATVP is struggling with a shrinking securities market. These sector-specific issues should take priority over any changes in the supervisory architecture, not least because institutional reorganization risked disrupting supervisory effectiveness. Indeed, international experience illustrates that such organizational changes experience high staff turnover rates and a decline in morale during the transition period. Thus, changes to the supervisory architecture should be meticulously planned and implemented gradually. The ultimate direction for the supervisory architecture should also be considered in light of the proposed amendment to the Euro area supervisory architecture.

\section{B. Macroprudential Framework}

\section{Systemic risk analysis}

33. The BOS has various tools for detecting and monitoring systemic risk. These include aggregate indicators of imbalances (balance sheets, soundness indicators, and asset prices), indicators of market conditions, metrics of concentration risk, and stress tests. These 
tools are described in the periodic BOS's publications (Financial Stability Review and Report on the Stability of the Slovenian Banking System). Internal surveillance reports are produced on a monthly basis, and overall market conditions are monitored on a daily basis.

\section{There are gaps in the data on financial stability analysis which should be}

addressed. In particular, the data on households are not at the same level of granularity as for the corporate sector, despite the vulnerabilities posed by this sector. Also, the information on banks' subsidiaries in the former Yugoslavia is not sufficiently detailed for financial stability analysis. In general, the BOS should take a proactive role in cooperating with other agencies that provide statistics in order to ensure that data needs for financial stability purposes can be met. Data on real estate markets could be further improved, for example on the coverage of the sale of housing from bankruptcy estates, for a more complete picture of the market.

\section{Instruments to address systemic risks}

35. The BOS has deployed various macroprudential measures both during the boom period and during the subsequent burst. Examples of regulatory tightening during the boom period include increased capital requirements on some rapidly growing bank exposures (such as loans for management buy-out, which had a risk weight of 150 percent), and a prudential provisioning buffer following the IFRS introduction in $2006 .{ }^{9}$ The BOS also warned banks and the general public against mounting risks, for example the risks associated with lending in Swiss francs to unhedged borrowers (which was very popular in Slovenia as elsewhere in the region in mid-2000s).

36. However, a recent measure — the counter-cyclical tax on banks—adopted in August 2011 creates distortions and should be abolished. The stated intention of this tax was to encourage bank lending, and individual banks that expanded their loans by at least 5 percent on an annual basis are exempt. But this tax may also unduly distort bank behavior by stimulating the extension of loans without proper credit risk assessment, or by devising ways to circumvent the tax. The tax is also anti-competitive as it penalizes locally-owned banks, which have a larger share of liquid assets compared to foreign-owned banks.

\section{Legal aspects of macroprudential oversight}

37. There is effective cooperation between the three regulatory agencies on issues of macroprudential oversight. The Coordinating Group, which comprises the minister of finance, governor and vice governor of the BOS or banking supervision department director of the BOS, directors of AZN and ATVP, and the group's secretary, is tasked with

\footnotetext{
${ }^{9}$ The IFRS introduction resulted in some over-provisioning in banks under the IFRS treatment. The BOS required banks to maintain the difference between the provisions formed under the previous system and the newly required provisions ("provisioning buffer"). This buffer was discontinued in 2008.
} 
identifying and monitoring systemic risks, as well as considering ways to address these risks. There is also a Commission for mutual cooperation, which provides for more operational coordination between the three supervisory agencies.

\section{However, a fully fledged macroprudential mandate is not enshrined in}

legislation. Although each of the financial sector supervisory agencies-BOS, AZN, and ATVP — contribute de facto to the stability of the Slovenian financial system, none of these agencies' statutory framework includes a de jure responsibility to do so. ${ }^{10}$ In fact, the existing laws do not even require that these agencies ensure the stability of their respective financial sectors - their sole responsibility appears to be ensuring that regulated financial institutions follow prudential rules.

\section{Each financial regulatory agency's mandate should be expanded to include}

macroprudential oversight. This could be achieved by ensuring that the laws governing the regulatory agencies include: (i) the responsibility for sectoral stability as the ultimate objective of sectoral supervision; (ii) the responsibility to contribute to the stability of the financial system as a whole by identifying, monitoring, and mitigating systemic risk, and cooperating with other agencies with a macro-prudential mandate; and (iii) the authority to use existing powers for macroprudential purposes and the authority to propose additional powers where needed. ${ }^{11}$ The BOS should be given the leading role in systemic risk assessment. Macroprudential oversight decisions and their motivations should be made public in a timely manner, taking into consideration the need for confidentiality on specific institutions. The macroprudential authority should be ultimately accountable to the national parliament.

\section{Regulation and Supervision}

\section{Banks}

40. The banking sector regulatory and supervisory frameworks are generally in line with international standards. With the accession of Slovenia to the EU, BOS has strengthened and expanded the bank supervisory regime by harmonizing banking regulation in Slovenia with EU standards. BOS has fully implemented Basel II capital framework, and work is under way to introduce Basel III. A large amount of information is gathered and

\footnotetext{
${ }^{10}$ The reference to financial stability in Article 4 of the BOS Act is framed by the ESCB's monetary policy objective for the Euro area. Arguably, this provision, which appears to concern the Slovenian transmission mechanism for the ESCB's monetary policy, cannot be construed as a domestic financial stability mandate. Even if one were to argue the contrary, this provision would be an insufficient legal basis for utilizing microprudential powers for macroprudential purposes.

${ }^{11}$ For example, the powers to acquire data from unregulated market participants and/or to expand the regulatory perimeter to these entities.
} 
analyzed through on-site and off-site supervision, and the authorities generally demand prompt correction of routine deficiencies detected in supervised institutions. BOS takes the lead in coordinating supervisory activities of Slovenia's two largest banks which have a presence in foreign markets.

41. However, there is room for improvement in bank supervision. The laws and regulations governing risk management are mostly derived from the EU directives and CEBS/EBA guidelines (and are aligned with the Basel standards), and the only purely domestic regulation addresses liquidity risk, which fills the gap that exists at the EU level. Nonetheless, as in many countries around the world, the crisis revealed the need to strengthen risk management, to ensure that supervisors are more forward looking and proactive in identifying and preventing banks from building up credit risk. The reporting of problem assets lacks granularity, and the provisioning of NPLs at 41 percent seems relatively low. As a result, there is a risk that impaired assets are somewhat under-provisioned.

\section{In particular, there is a need to strengthen the off-site supervision of banks.}

Whereas supervisory resources have been expanded since the FSAP of 2003, the off-site supervision function is understaffed. This constrains its ability to undertake in-depth analyses and monitoring as would be desirable. A significant increase in the off-site staff along with targeted hiring of on-site resources and better leveraging of internal control assessments and audits would permit a more proactive, more intensive, more forward looking, and more effective risk-based supervision.

\section{The banking supervision framework also suffers from weaknesses in several} specific areas. ${ }^{12}$ In particular, these include inadequate legal protection of bank supervisors in civil and criminal court proceedings, and insufficient requirements for major acquisitions by banks. Regarding the latter, while BOS is empowered to authorize banks' acquisition of other banks and review the qualifications of senior management, it does not have such power over the acquisition of non-bank financial companies. The banks can acquire such companies regardless of their financial condition, quality of risk management systems, and capacity to manage these entities, which bear a large degree of risk, notwithstanding their size, in view of the specialized nature of their activities.

44. BOS has special challenges in supervising the state-controlled banks. These institutions are the least profitable, have greater asset quality problems, and require greater amounts of capital relative to their risk profile. Government interference had contributed significantly to these problems, and has impeded the ability of these institutions to adopt appropriate prudential risk management standards as required by the BOS.

\footnotetext{
${ }^{12}$ Annex I summarizes the main findings of the assessment of the Basel Core Principles for Effective Banking Supervision.
} 


\section{Insurance companies}

45. AZN has an effective system of both on-site and off-site supervision of insurance companies. The staff size of AZN and the time allocated for on-site examinations in the regular course of supervision are adequate. The reporting requirements are comprehensive, and significant improvements are planned to enhance filing data electronically in a more timely fashion when legal issues surrounding electronic signatures are resolved. AZN has the authority to order an insurer to take preventive and corrective measures to act according to regulatory rules.

\section{Although AZN has adequate staff resources, it is confronted with a} compensation scheme that may potentially impede attraction and retention of talented staff. As of now, AZN seems to be able to attract highly skilled staff, with education and certifications necessary to carry out the current functions as mandated by the Insurance Act. It also provides adequate training. However, compensation in AZN is artificially capped irrespective of market requirements by the Public Agencies Act (which regulates the overall status of public agencies), Civil Servants Act (which regulates public servants and employment), and the Public Sector Wage System Act (which regulates wages).

\section{The adoption of Solvency II framework represents a major challenge to the} insurance sector. The adoption and implementation of Solvency II, scheduled for January 2014, will be one of the most important areas for AZN in the next few years. AZN must monitor Solvency II developments on an ongoing basis, which will require changes to current legislation and IT developments to ensure that adequate staffing and expertise are available. The most significant change in Solvency II will be the possibility to use internal models to determine insurers' capital which is currently not permitted in Slovenia. ${ }^{13}$ A few larger insurers may decide to use internal models in the future, which will require supervisors to develop skills to enable them to assess the quality of the models.

\section{Securities market}

48. Slovenia has a comprehensive legislative and institutional framework for effective supervision of the securities market. This reflects the implementation of all relevant EU Directives and enforcement of EU Regulations. The ATVP is a small agency but has sufficient human and other resources to meet its responsibilities effectively given that the securities market and the number of intermediaries active in it is also small. Staff appears knowledgeable and well-motivated. Sophisticated IT systems have been developed to make the best use of scarce resources. Work on international cooperation and coordination,

\footnotetext{
${ }^{13}$ The capital requirements for insurance companies are not calculated on risk based approach but as a function of mathematical provisions and capital at risk in the case of life insurance and a function of premiums written or claims paid for non-life.
} 
particularly to meet the demands of the European Securities and Markets Authority, is a significant and growing element. Effectiveness of implementation of the law by ATVP also appears high.

49. However, some issues remain. These concern, for example, the political independence of the ATVP which might limit its effectiveness. The Market in Financial Instruments Act matches the recognized global standard for political independence of a securities market regulator (as endorsed by IOSCO), but the Public Agencies Act detracts from that standard in a number of its provisions. ${ }^{14}$ Another shortcoming is the limited application of enforcement powers. These powers do not apply to banks even though the ATVP is their supervisor for investment activities and services. Also, as in the case with AZN, compensation and inflexible career structures are an impediment to an efficient human resources program.

\section{Crisis Management and Safety Nets}

\section{The BOS's powers to deal with a failing bank are limited, and the bank} resolution tool-kit needs to be strengthened. The special administrators, which BOS can appoint, focus their work on assessing a failing bank's financial situation and possible remedies. The mandate of special administrators should be broadened to include the design and implementation (after BOS approval) of a restructuring plan for the bank, and - as an alternative to restructuring - the preparation of the bank for orderly liquidation. This would require granting special administrators strong and explicit restructuring powers, and establishing effective restructuring tools. ${ }^{15}$ Given the challenges Slovenia faces, there may be merit in moving ahead with such reforms ahead of finalization of EU directives in these areas, as such finalization may take some time. These recommendations are in line with the proposed draft of the EU directive.

51. The restructuring powers would require the possibility for the administrator to fully take over the powers of all decision-making bodies of the failing bank, the management board, the supervisory board and the general assembly of shareholders. The restructuring tools would include, inter alia: (i) rapid recapitalization of banks without shareholders' agreement, (ii) transfer of assets (including businesses and subsidiaries), liabilities, and combined portfolios of assets and liabilities ("purchase and assumption transactions") to third party acquirers, and (iii) if such acquirers do not present themselves, chartering bridge banks to transfer assets and liabilities to.

\footnotetext{
${ }^{14}$ Examples include Article 48, Minister's right exercise supervision over the agency's affairs; Articles 15 (limiting the protection from legal liability); Articles 23 and 24 (premature dismissal of the Director and Council) Article 36 (limitations to the Agency's action program).

${ }^{15}$ It should be noted that appointing a special administrator on its own, without application of an effective resolution power shortly thereafter, could be destabilizing as creditors may run.
} 
52. The DGS should be redesigned, consistent with the FSB's Key Attributes and the EU's recent draft directive on these issues, from a pay-box system into an effective tool for bank resolution. In particular, the following features should be considered—provided that they are in line with the upcoming EU Directives: ${ }^{16}$

- $\quad$ Ex ante funding. The DGS should be funded ex ante by contributions paid by banks. These contributions should be invested in liquid instruments or deposited in an account at the BOS. If DGS funds are insufficient for payouts, the BOS should for the time being continue to be authorized to provide funding, respectful of the conditions for monetary financing. In the future such responsibilities for supporting the DGS' financing should be moved from the BOS to the government, which may guarantee the DGS's financing from markets or provide liquidity directly to the DGS.

- Contribution to resolution. The DGS should be allowed to support certain bankrestructuring transactions, with the qualification that its support should not exceed what it would have paid out to in a liquidation (i.e. a cap), subject to exemption for systemic cases. In particular, the DGS should be authorized to cover the 'funding gap' by compensating the acquiring third party in case assets are insufficient to offset insured deposits.

- Depositor preference. Insured depositors and the DGS should be given priority rights over the estate of the failed bank. Such priority protects the contributing banks and ultimately the public purse, and simplifies purchase and assumption transactions.

53. The legal framework for official liquidity and solvency support needs to be strengthened. Specifically:

- $\quad$ Liquidity support by the BOS. The BOS Act does not provide for an explicit legal basis for ELA operations. Due to legal changes stemming from Slovenia's accession to the Euro area, it is questionable whether the general provisions on credit operations by the BOS with credit institutions would suffice for this purpose. With a view to enhancing legal certainty, the legal basis for ELA operations for financial stability purposes should be clarified.

- Solvency support by the government. At the height of the global financial crisis an additional legal basis was created in the Public Finance Act to allow for extrabudgetary bank guarantees, and liquidity and capital support for banks. These provisions expired by end-2010. Consequently, any state support would require a

\footnotetext{
${ }^{16}$ See FSB's "Key Attributes of Effective Resolution Regimes for Financial Institutions", the European Commission's proposed Directive "Establishing a Framework for the Recovery and Resolution of Credit Institutions and Investment Firms" and the proposed Directive "On Deposit Guarantee Schemes."
} 
lengthy appropriation procedure through parliament. The Public Finance Act should reintroduce a standing authorization for the government to provide rapid financial support to undercapitalized banks in the context of systemic crisis management. To address moral hazard concerns, it would be necessary to ensure the following: close interaction with the BOS in determining the need for solvency support from the government; attribution of losses to existing shareholders by reducing capital; improvement to the bank's governance and profitability through the BOS' approval and follow-up of the bank's reform plan; and robust ex-post transparency requirements to the parliament.

\section{The operational arrangements for a crisis management framework need to be}

strengthened. A plan for the operation of competent institutions during an unexpected crisis (which is referred to in the existing rules on mutual cooperation of supervisory authorities) has not yet been prepared and adopted by the Coordinating Group. Such a plan should define the respective roles of the MOF and the supervisory agencies - in particular BOS — during a systemic crisis. In accordance with the rules on mutual cooperation of supervisory authorities, the Coordination Group should continue to monitor the implementation of said crisis plan. ${ }^{17}$ Conducting periodic (for example, annual) crisis simulations involving all stakeholders would help ensure some comfort that the contingency plans can actually be executed.

\section{E. Anti-Money Laundering and Combating Financing of Terrorism (AML/CFT) ${ }^{18}$}

\section{Slovenia has introduced a number of measures to strengthen its AML/CFT} regime since the 2005 MONEYVAL assessment. In particular, the legislation was amended to incorporate the Third EU Money Laundering Directive and its Implementing Directive

\footnotetext{
${ }^{17}$ For operational clarity and legal certainty, the rules on mutual cooperation should be restructured to provide a clearer distinction between crisis prevention (i.e., in particular mitigating through macroprudential oversight systemic risk that is building up) and crisis management (i.e., addressing a systemic crisis, including mitigating its consequences, through coordinated action by financial agencies and the MOF). One distinction between the two would be the leading role of the MOF in crisis management, but not in macroprudential oversight.

${ }^{18}$ A comprehensive AML/CFT assessment of Slovenia was last conducted by MONEYVAL in July 2005, i.e., more than five years ago. Therefore, a full AML/CFT reassessment is required according to IMF Board decisions regarding the incorporation of AML/CFT into the FSAP. Given that a new assessment methodology will be published in early 2013, the authorities are currently in discussions with MONEYVAL to schedule the assessment sometime early in the next round of evaluations against a revised standard. A ROSC will be forwarded to the IMF and subsequently circulated to the Board upon adoption of the mutual evaluation report by the MONEYVAL Plenary.
} 
into national law. Follow-up actions have also been taken by the authorities towards remedying shortcomings identified in the targeted 2010 assessment by MONEVAL. ${ }^{19}$

56. Although a relatively minor deficiency exists, money laundering and financing of terrorism is criminalized largely in accordance with the relevant United Nations Conventions. The seizure and confiscation framework under Slovenian law is comprehensive overall. However, the low level of convictions and confiscations related to money laundering and other proceeds-generating crimes indicates the need to strengthen and facilitate money laundering related investigations, prosecutions and confiscations under the current framework. Slovenia generally relies on the EU framework for freezing of terrorist assets to implement United Nations Securities Council resolution 1267 (1999) and 1373 (2001) and related EU regulations. However, efforts should be made to develop comprehensive domestic procedures and guidance to facilitate implementation of the existing measures.

57. Slovenia has a broadly sound legal structure for the major preventive measures against money laundering/terrorist financing in the financial sector as well as for designated non-financial businesses and professions (DNFBPs), while concerns remain about insufficient implementation by non-banking financial intermediaries and the majority of DNFBPs. For the financial sector as a whole, regulatory and supervisory frameworks for overseeing implementation of the preventive measures are generally in place. However, supervision of non-bank financial intermediaries, notably the insurance sector, should be strengthened, and more sector-specific guidance should be issued. Furthermore, none of the supervisors appear to be utilizing their sanctioning powers effectively. Casinos excepted, the majority of DNFBPs lack awareness and the necessary guidance to fulfill their AML/CFT obligations.

\section{The Office for Money Laundering Prevention (OMLP), Slovenia's financial} intelligence unit, appears to be operating effectively. The OMLP and law enforcement agencies appear to be responsive in exchanging information with and providing mutual legal assistance to their foreign counterparts, supported in this by a sound legal framework. Deficiencies related to the criminalization of terrorist financing and shortcomings in the confiscation regime may undermine, however, the effectiveness of mutual legal assistance.

\footnotetext{
${ }^{19}$ The overview of Slovenia's AML/CFT regime is based on the March 2010 MONEYVAL targeted assessment, its subsequent follow-up reports, and information obtained by the FSAP mission. According to MONEYVAL's internal procedures, the 2010 report addresses only a sub-set of FATF Recommendations. Nevertheless, all of the most important FATF Recommendations (i.e., the 16 Core/Key Recommendations) and the Recommendations for which Slovenia was rated Non-Compliant or Partially Compliant in the Third Round of Mutual Evaluations have been reassessed.
} 
Table 2. Slovenia: Selected Macroeconomic Indicators 2008-2014

(Annual percentage change, unless noted otherwise)

\begin{tabular}{|c|c|c|c|c|c|c|c|}
\hline & \multirow[b]{2}{*}{2008} & \multirow[b]{2}{*}{2009} & \multirow[b]{2}{*}{2010} & \multirow[b]{2}{*}{2011} & \multicolumn{3}{|c|}{ Projections } \\
\hline & & & & & 2012 & 2013 & 2014 \\
\hline Real GDP & 3.4 & -7.8 & 1.2 & 0.6 & -2.2 & -1.0 & 1.7 \\
\hline Domestic demand & 3.2 & -10.0 & -0.2 & -0.7 & -4.2 & -1.9 & 1.2 \\
\hline Private consumption & 2.3 & 0.1 & 1.3 & 0.9 & -0.7 & -0.9 & 1.5 \\
\hline Public consumption & 5.9 & 2.5 & 1.5 & -1.2 & -7.9 & -3.1 & 0.1 \\
\hline Gross capital formation & 3.1 & -33.8 & -5.8 & -4.6 & -9.4 & -3.5 & 1.5 \\
\hline Net exports (contribution to growth) & 0.1 & 2.7 & 1.5 & 1.4 & 1.6 & 0.8 & 0.5 \\
\hline Exports of goods and services & 4.0 & -16.7 & 10.1 & 7.0 & 1.4 & 2.6 & 4.1 \\
\hline Imports of goods and services & 3.7 & -19.5 & 7.9 & 5.2 & -0.7 & 1.7 & 3.7 \\
\hline Output gap (in percent of potential GDP) & 9.2 & -1.0 & -0.9 & -1.3 & -4.1 & -5.5 & -4.3 \\
\hline \multicolumn{8}{|l|}{ Prices } \\
\hline GDP deflator & 4.1 & 3.6 & -1.1 & 1.0 & 1.4 & 1.3 & 1.5 \\
\hline Consumer prices (national definition, period average) & 5.7 & 0.9 & 1.8 & 1.8 & 2.2 & 1.5 & 1.9 \\
\hline \multicolumn{8}{|l|}{ Employment and wages } \\
\hline Unemployment rate (in percent, ILO definition) & 4.4 & 5.9 & 7.3 & 8.2 & 8.8 & 9.0 & 8.7 \\
\hline Unemployment rate (in percent, registered) & 6.7 & 9.2 & 10.7 & 10.2 & 10.7 & 10.9 & 10.6 \\
\hline Nominal wages (all sectors) & 8.3 & 3.5 & 3.9 & 2.0 & 0.3 & -1.1 & 2.1 \\
\hline Real wages (all sectors) & 2.5 & 2.6 & 2.0 & 0.2 & -1.2 & -1.9 & 0.4 \\
\hline Unit labor cost (all sectors) & 7.5 & 10.2 & 0.0 & -0.4 & 0.5 & -0.9 & 0.8 \\
\hline \multicolumn{8}{|l|}{ Public finance (percent of GDP) } \\
\hline General government balance $1 /$ & -0.3 & -5.5 & -5.3 & -5.6 & -3.5 & -3.4 & -3.1 \\
\hline Primary balance & 0.5 & -4.6 & -4.1 & -4.3 & -1.8 & -1.2 & -0.5 \\
\hline Structural balance & -3.9 & -5.1 & -4.9 & -3.7 & -1.7 & -1.0 & -1.3 \\
\hline General government debt & 22.0 & 35.0 & 38.6 & 46.9 & 52.1 & 55.6 & 57.3 \\
\hline \multicolumn{8}{|l|}{ Monetary and financial indicators } \\
\hline Credit to the private sector & 16.7 & 3.2 & 1.9 & -2.6 & $\ldots$ & $\ldots$ & $\ldots$ \\
\hline Lending rates $1 /$ & 6.2 & 5.3 & 4.9 & 5.0 & $\ldots$ & $\ldots$ & $\ldots$ \\
\hline Deposit rates $2 /$ & 4.3 & 2.5 & 1.8 & 2.2 & $\ldots$ & $\ldots$ & $\ldots$ \\
\hline Government bond yield (10-year, average) 3/ & 4.7 & 4.4 & 3.8 & 4.2 & $\ldots$ & $\ldots$ & $\ldots$ \\
\hline \multicolumn{8}{|l|}{ Balance of payments (percent of GDP) } \\
\hline Trade balance (goods) & -6.4 & -1.4 & -2.8 & -2.9 & -2.0 & -1.8 & -1.8 \\
\hline Current account balance & -6.2 & -0.7 & -0.6 & 0.0 & 0.8 & 1.1 & 1.2 \\
\hline Gross external debt (percent of GDP, end-period) & 105.3 & 113.3 & 114.4 & 111.2 & 114.0 & 115.9 & 116.2 \\
\hline Nominal effective exchange rate $(2000=100)$ & 101.4 & $104.0^{\prime}$ & 100.6 & 101.1 & $\ldots$ & $\ldots$ & $\ldots$ \\
\hline Real effective exchange rate $(2000=100$, CPI-based $)$ & 104.0 & $106.7^{\top}$ & 103.1 & 102.4 & $\ldots$ & $\ldots$ & $\ldots$ \\
\hline \multicolumn{8}{|l|}{ Savings and investment (percent of GDP) } \\
\hline National saving & 25.6 & 21.5 & 20.5 & 20.1 & 19.3 & 19.4 & 19.7 \\
\hline Government & 4.3 & -0.5 & -0.5 & -1.8 & -0.1 & 0.8 & 0.7 \\
\hline Non-government & 21.3 & 21.9 & 21.0 & 21.9 & 19.4 & 18.6 & 18.9 \\
\hline Gross capital formation & 31.8 & 22.1 & 21.1 & 20.1 & 18.5 & 18.3 & 18.4 \\
\hline Government & 3.4 & 3.6 & 3.7 & 2.8 & 2.5 & 3.1 & 2.8 \\
\hline Non-government & 28.4 & 18.5 & 17.4 & 17.3 & 16.0 & 15.2 & 15.7 \\
\hline Foreign saving & -6.2 & -0.7 & -0.6 & 0.0 & 0.8 & 1.1 & 1.2 \\
\hline
\end{tabular}

Sources: Data provided by the Slovenian authorities; and IMF staff calculations and projections.

1 / Floating or up to one year fixed rate for new loans to non-financial corporations over 1 million euros.

2/ For household time deposits with maturity up to one year.

3/ Eurostat Data 
Table 3. Slovenia: Structure of the Financial System 2006-2011

\begin{tabular}{|c|c|c|c|c|c|c|c|c|c|c|c|c|c|c|c|c|c|c|}
\hline & \multicolumn{6}{|c|}{ Assets (EUR million) } & \multicolumn{6}{|c|}{ Assets (in \% of total) } & \multicolumn{6}{|c|}{ Assets (in \% of GDP) } \\
\hline & 2006 & 2007 & 2008 & 2009 & 2010 & 2011 & 2006 & 2007 & 2008 & 2009 & 2010 & 2011 & 2006 & 2007 & 2008 & 2009 & 2010 & 2011 \\
\hline $\begin{array}{l}\text { Monetary financial institutions }{ }^{1} \\
\text { of which: }\end{array}$ & 34,080 & 44,505 & 47,948 & 52,009 & 50,760 & 49,283 & 73.6 & 73.2 & 76.3 & 76.6 & 75.9 & 75.8 & 109.8 & 128.8 & 128.6 & 147.3 & 143.3 & 137.8 \\
\hline Commercial banks & 33,868 & 44,249 & 47,628 & 51,612 & 50,319 & 48,788 & 73.1 & 72.8 & 75.8 & 76.1 & 75.2 & 75.1 & 109.1 & 128.0 & 127.8 & 146.2 & 142.1 & 136.4 \\
\hline Large locally-ow ned banks & 21,438 & 27,111 & 29,192 & 32,331 & 31,662 & 30,507 & 46.3 & 44.6 & 46.4 & 47.6 & 47.3 & 46.9 & 69.1 & 78.4 & 78.3 & 91.6 & 89.4 & 85.3 \\
\hline Small locally-ow ned banks & 2,505 & 4,962 & 3,611 & 4,073 & 4,231 & 3,981 & 5.4 & 8.2 & 5.7 & 6.0 & 6.3 & 6.1 & 8.1 & 14.4 & 9.7 & 11.5 & 11.9 & 11.1 \\
\hline Foreign-ow ned banks & 9,926 & 12,176 & 14,825 & 15,208 & 14,425 & 14,299 & 21.4 & 20.0 & 23.6 & 22.4 & 21.6 & 22.0 & 32.0 & 35.2 & 39.8 & 43.1 & 40.7 & 40.0 \\
\hline Savings banks & 211 & 255 & 320 & 397 & 441 & 495 & 0.5 & 0.4 & 0.5 & 0.6 & 0.7 & 0.8 & 0.7 & 0.7 & 0.9 & 1.1 & 1.2 & 1.4 \\
\hline $\begin{array}{l}\text { Non-monetary financial institutions } \\
\text { of which: }\end{array}$ & 12,245 & 16,264 & 14,924 & 15,856 & 16,143 & 15,711 & 26.4 & 26.8 & 23.7 & 23.4 & 24.1 & 24.2 & 39.4 & 47.1 & 40.0 & 44.9 & 45.6 & 43.9 \\
\hline Insurers² & 3,895 & 5,035 & 5,151 & 5,660 & 6,041 & 6,108 & 8.4 & 8.3 & 8.2 & 8.3 & 9.0 & 9.4 & 12.5 & 14.6 & 13.8 & 16.0 & 17.1 & 17.1 \\
\hline Pension companies/funds', 3 & 893 & 1,001 & 1,041 & 1,287 & 1,538 & 1,518 & 1.9 & 1.6 & 1.7 & 1.9 & 2.3 & 2.3 & 2.9 & 2.9 & 2.8 & 3.6 & 4.3 & 4.2 \\
\hline Investment funds & 2,845 & 4,138 & 1,912 & 2,234 & 2,294 & 1,816 & 6.1 & 6.8 & 3.0 & 3.3 & 3.4 & 2.8 & 9.2 & 12.0 & 5.1 & 6.3 & 6.5 & 5.1 \\
\hline Leasing companies 4,5 & 4,052 & 5,328 & 6,146 & 6,094 & 5,731 & 5,731 & 8.7 & 8.8 & 9.8 & 9.0 & 8.6 & 8.8 & 13.1 & 15.4 & 16.5 & 17.3 & 16.2 & 16.0 \\
\hline BHs, MCs, others ${ }^{5}$ & 560 & 762 & 674 & 581 & 538 & 538 & 1.2 & 1.3 & 1.1 & 0.9 & 0.8 & 0.8 & 1.8 & 2.2 & 1.8 & 1.6 & 1.5 & 1.5 \\
\hline Total & 46,325 & 60,769 & 62,872 & 67,865 & 66,903 & 64,993 & 100.0 & 100.0 & 100.0 & 100.0 & 100.0 & 100.0 & 149.2 & 175.8 & 168.6 & 192.2 & 188.9 & 181.8 \\
\hline
\end{tabular}

The figures for leasing companies, brokerage houses, management companies and others are obtained from the AJPES database of closing accounts .

1 Monetary financial institutions do not include the central bank.

${ }^{2}$ The latest figures are available for the end of the third quarter of 2011.

${ }_{3}^{3}$ The First Pension Fund is included among pension funds.

${ }^{4}$ The figures for the number of leasing companies comprise the number of companies being listed by the BAS's leasing committee.

5 Total assets in 2011 according to the figures for the end of 2010

Sources: Bank of Slovenia, ISA, SMA, AJPES, BAS 
Table 4. Slovenia: Financial Soundness Indicators by Banking Group, 2008-11

(In percent unless specified otherwise)

\begin{tabular}{|c|c|c|c|c|c|c|c|c|c|c|c|c|c|}
\hline & \multirow[b]{2}{*}{$\begin{array}{r}2008 \\
\text { Total } \\
\text { banking } \\
\text { sector }\end{array}$} & \multicolumn{4}{|c|}{2009} & \multicolumn{4}{|c|}{2010} & \multicolumn{4}{|c|}{2011} \\
\hline & & $\begin{array}{r}\text { Total } \\
\text { banking } \\
\text { sector } \\
\end{array}$ & $\begin{array}{r}\text { Large } \\
\text { domestic } \\
\text { banks } \\
\end{array}$ & $\begin{array}{r}\text { Small } \\
\text { domestic } \\
\text { banks } \\
\end{array}$ & $\begin{array}{c}\text { Foreign } \\
\text { banks }\end{array}$ & $\begin{array}{r}\text { Total } \\
\text { banking } \\
\text { sector } \\
\end{array}$ & $\begin{array}{r}\text { Large } \\
\text { domestic } \\
\text { banks } \\
\end{array}$ & $\begin{array}{r}\text { Small } \\
\text { domestic } \\
\text { banks } \\
\end{array}$ & $\begin{array}{r}\text { Foreign } \\
\text { banks }\end{array}$ & $\begin{array}{r}\text { Total } \\
\text { banking } \\
\text { sector }\end{array}$ & $\begin{array}{r}\text { Large } \\
\text { domestic } \\
\text { banks } 1 /\end{array}$ & $\begin{array}{r}\text { Small } \\
\text { domestic } \\
\text { banks } \\
\end{array}$ & $\begin{array}{r}\text { Foreign } \\
\text { banks }\end{array}$ \\
\hline \multicolumn{14}{|l|}{ Capitalization } \\
\hline Regulatory capital to risk-weighted assets & 11.7 & 11.7 & 11.9 & 11.3 & 11.3 & 11.3 & 11.3 & 11.4 & 11.4 & 11.9 & 11.8 & 11.6 & 12.3 \\
\hline Regulatory Tier 1 capital to risk-weighted assets & 9.0 & 9.0 & 8.9 & 8.9 & 9.5 & 8.6 & 8.2 & 9.0 & 9.7 & 9.4 & 8.8 & 9.5 & 10.7 \\
\hline \multicolumn{14}{|l|}{ Asset Quality } \\
\hline Nonperforming loans net of provisions to capital & 30.2 & 36.7 & 37.7 & 33.0 & 35.3 & 50.1 & 54.1 & 54.9 & 39.2 & 70.2 & 84.6 & 81.5 & 37.3 \\
\hline Nonperforming loans to total gross loans & 4.2 & 5.8 & 6.3 & 6.1 & 4.7 & 8.3 & 9.2 & 9.0 & 6.1 & 11.9 & 14.3 & 13.4 & 6.2 \\
\hline Provisions to Non Performing Loans & $\ldots$ & 31.1 & 31.1 & 36.2 & 30.6 & 36.9 & 37.9 & 31.6 & 36.6 & 40.4 & 42.5 & 32.6 & 35.9 \\
\hline \multicolumn{14}{|l|}{ Sectoral distribution of loans } \\
\hline Manufacturing & 14.3 & 13.7 & 13.7 & 11.9 & 14.1 & 13.5 & 13.7 & 11.6 & 13.4 & 13.1 & 13.3 & 12.0 & 12.9 \\
\hline Construction and real estate & 9.2 & 9.2 & 9.1 & 10.5 & 8.9 & 9.6 & 9.7 & 9.8 & 9.2 & 9.7 & 10.0 & 9.8 & 9.0 \\
\hline Wholesale and trade & 10.8 & 9.9 & 8.3 & 12.5 & 12.4 & 9.7 & 8.2 & 11.4 & 12.3 & 9.2 & 8.1 & 10.6 & 11.3 \\
\hline Transportation & 4.4 & 4.6 & 4.6 & 1.4 & 5.3 & 4.6 & 4.6 & 1.1 & 5.5 & 4.7 & 4.6 & 1.1 & 6.0 \\
\hline Financial & 15.6 & 16.0 & 18.5 & 15.2 & 11.4 & 17.4 & 20.1 & 18.5 & 11.4 & 17.3 & 20.4 & 20.1 & 10.3 \\
\hline Households & 16.6 & 16.9 & 14.7 & 12.1 & 22.3 & 18.3 & 14.9 & 12.5 & 27.1 & 18.7 & 14.7 & 12.5 & 28.7 \\
\hline Non residents & 9.1 & 8.1 & 10.6 & 10.5 & 2.8 & 8.1 & 10.6 & 10.5 & 2.2 & 7.2 & 9.2 & 9.5 & 2.5 \\
\hline Other & 19.9 & 21.7 & 20.5 & 26.0 & 22.9 & 18.9 & 18.1 & 24.6 & 18.9 & 20.1 & 19.8 & 24.4 & 19.3 \\
\hline FX-loans to total loans & 6.3 & 5.1 & 4.6 & 0.9 & 7.1 & 4.5 & 3.7 & 0.7 & 7.1 & 5.7 & 4.0 & 0.9 & 10.1 \\
\hline FX-loans to total loans (nonbanking sector) & 5.9 & 4.8 & 4.0 & 0.6 & 7.0 & 4.3 & 3.5 & 0.5 & 6.5 & 5.2 & 3.4 & 0.5 & 9.2 \\
\hline \multicolumn{14}{|l|}{ Profitability } \\
\hline Return on assets & 0.5 & 0.2 & 0.0 & 0.3 & 0.5 & -0.2 & -0.5 & 0.1 & 0.2 & -0.9 & -1.3 & -0.9 & 0.2 \\
\hline Return on equity & 7.1 & 2.2 & 0.5 & 3.8 & 5.9 & -3.2 & -6.2 & 0.6 & 3.0 & -11.7 & -17.7 & -15.6 & 2.5 \\
\hline Interest margin to gross income & 65.7 & 61.3 & 60.6 & 56.1 & 64.8 & 63.6 & 61.9 & 67.8 & 67.7 & 65.4 & 64.9 & 61.6 & 67.3 \\
\hline Noninterest expenses to gross income & 62.5 & 54.8 & 52.3 & 56.2 & 61.8 & 57.9 & 58.3 & 56.3 & 57.1 & 39.3 & 52.6 & 32.5 & . \\
\hline \multicolumn{14}{|l|}{ Liquidity } \\
\hline Liquid assets to total assets & 13.9 & 13.8 & 17.3 & 16.4 & 6.1 & 14.2 & 17.4 & 15.9 & 7.0 & 13.5 & 15.8 & 16.0 & 7.7 \\
\hline Liquid assets to short-term liabilities & 34.8 & 36.2 & 41.9 & 33.5 & 20.3 & 42.9 & 51.4 & 38.3 & 22.9 & 40.3 & 47.1 & 41.4 & 23.9 \\
\hline
\end{tabular}

1/ Large domestic banks comprise six banks, of which four banks with a market share of around 80 percent are state-owned. 
Table 5. Slovenia: Stress Testing Macroeconomic Scenarios, 2012-13 1/

\begin{tabular}{|c|c|c|c|c|c|c|c|}
\hline & \multicolumn{3}{|c|}{ Baseline scenario } & \multicolumn{2}{|c|}{ Adverse scenario 1} & \multicolumn{2}{|c|}{ Adverse scenario 2} \\
\hline & 2011 & 2012 & $\overline{2013}$ & 2012 & 2013 & 2012 & 2013 \\
\hline & \multicolumn{7}{|c|}{ Macroeconomic variables, yearly changes (in \%) } \\
\hline GDP & -0.2 & -1.2 & 0.6 & -8.1 & 0.6 & -4.8 & -3.0 \\
\hline Private consumption & -0.3 & -1.1 & -0.8 & -2.0 & -0.7 & -4.0 & -4.4 \\
\hline Exports & 6.8 & 2.3 & 4.0 & -18.0 & 4.5 & -10.0 & -8.0 \\
\hline Unemployment & 8.1 & 9.0 & 9.5 & 9.6 & 11.0 & 9.3 & 10.4 \\
\hline EURIBOR 3M & 1.4 & 1.3 & 1.7 & 3.3 & 3.7 & 2.3 & 2.7 \\
\hline
\end{tabular}

Source: Bank of Slovenia and IMF staff estimates

$1 /$ Staff revised down growth projections following the completion of the stress testing exercise. The latest projections are shown in Table 2.

Table 6. Slovenia: Macro Scenario Stress Tests-Bottom-Up

\begin{tabular}{|c|c|c|c|c|c|}
\hline & \multirow[b]{2}{*}{2011} & \multicolumn{2}{|c|}{ BASELINE } & \multicolumn{2}{|c|}{ ADVERSE 1} \\
\hline & & 2012 & 2013 & 2012 & 2013 \\
\hline \multicolumn{6}{|l|}{ Banking system } \\
\hline CAR & 11.8 & 11.1 & 10.6 & 10.7 & 8.6 \\
\hline Capital shortfall (in $€ \mathrm{~m}$ ) & 0 & -1 & -60 & -37 & -518 \\
\hline Core Tier 1 ratio & 8.7 & 7.9 & 7.3 & 7.3 & 5.3 \\
\hline Core Tier 1 shortfall (in $€ \mathrm{~m}$ ) & -540 & -912 & $-1,211$ & $-1,252$ & $-1,867$ \\
\hline \multicolumn{6}{|l|}{ Large domestic banks } \\
\hline CAR & 11.7 & 10.8 & 10.1 & 9.7 & 7.9 \\
\hline Capital shortfall (in $€ \mathrm{~m}$ ) & 0 & 0 & -50 & -35 & -477 \\
\hline Core Tier 1 ratio & 7.9 & 6.9 & 6.1 & 5.7 & 3.8 \\
\hline Core Tier 1 shortfall (in $€ \mathrm{~m}$ ) & -523 & -822 & $-1,060$ & $-1,102$ & $-1,594$ \\
\hline \multicolumn{6}{|l|}{ Small domestic banks } \\
\hline CAR & 11.5 & 11.0 & 10.6 & 10.1 & 8.8 \\
\hline Capital shortfall (in $€ \mathrm{~m}$ ) & 0 & -1 & -4 & -1 & -9 \\
\hline Core Tier 1 ratio & 8.9 & 8.3 & 7.9 & 7.4 & 6.1 \\
\hline Core Tier 1 shortfall (in $€ \mathrm{~m}$ ) & -14 & -31 & -44 & -59 & -106 \\
\hline \multicolumn{6}{|l|}{ Foreign owned banks } \\
\hline CAR & 12.3 & 12.0 & 11.9 & 11.2 & 10.3 \\
\hline Capital shortfall (in $€ \mathrm{~m}$ ) & 0 & 0 & -6 & 0 & -32 \\
\hline Core Tier 1 ratio & 10.7 & 10.4 & 10.2 & 9.6 & 8.7 \\
\hline Core Tier 1 shortfall (in $€ m$ ) & -3 & -60 & -107 & -91 & -167 \\
\hline
\end{tabular}

Source: Bank of Slovenia 
Table 7. Slovenia: Macro Scenario Stress Tests-Top-Down

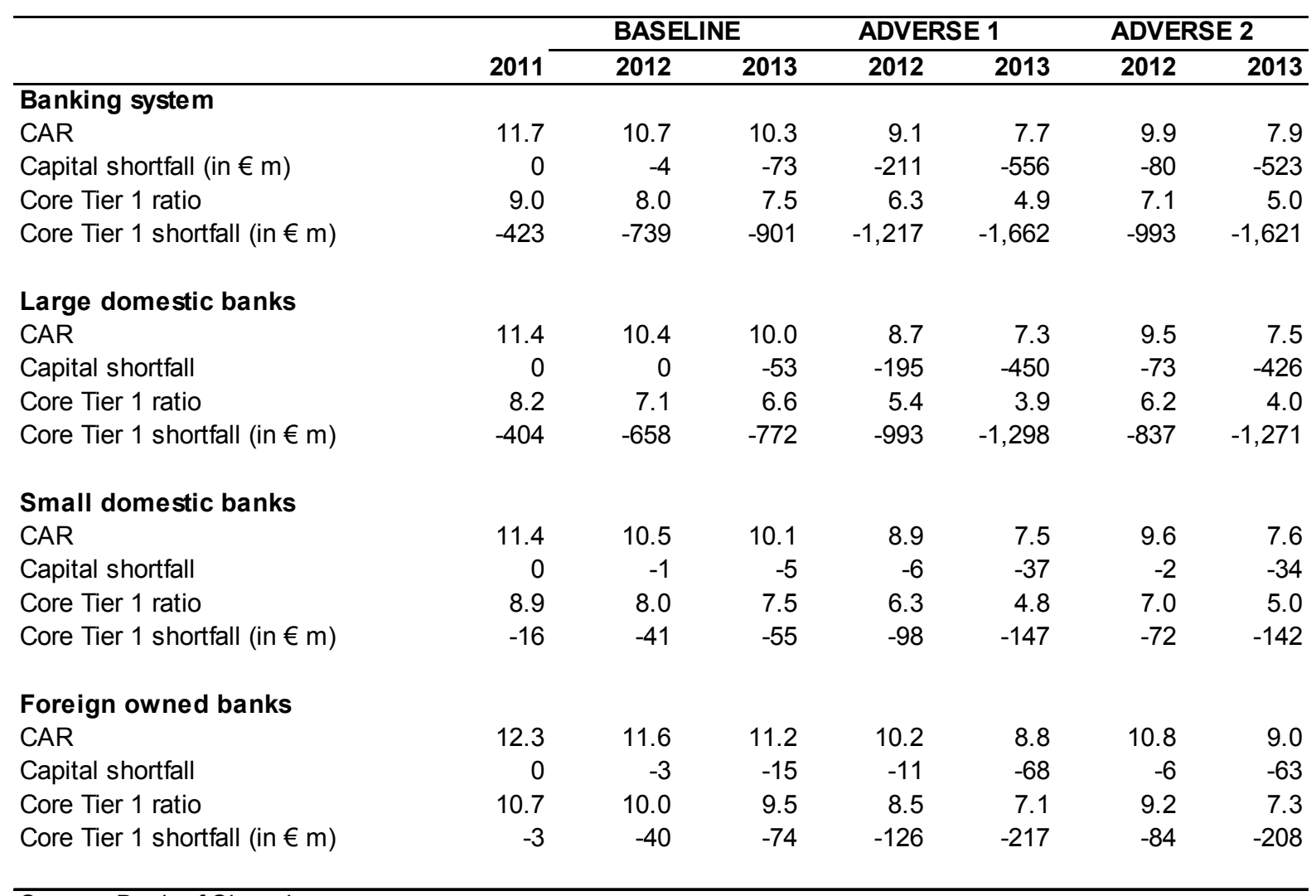

Source: Bank of Slovenia 
Table 8. Slovenia: Single Factor Stress Tests

\begin{tabular}{|c|c|c|c|c|c|c|c|c|}
\hline & \multicolumn{2}{|c|}{ Banking system } & \multicolumn{2}{|c|}{$\begin{array}{l}\text { Large domestic } \\
\text { banks }\end{array}$} & \multicolumn{2}{|c|}{$\begin{array}{l}\text { Small domestic } \\
\text { banks }\end{array}$} & \multicolumn{2}{|c|}{ Foreign banks } \\
\hline & 2011 & $\begin{array}{r}\text { post- } \\
\text { shock }\end{array}$ & 2011 & $\begin{array}{r}\text { post- } \\
\text { shock }\end{array}$ & 2011 & $\begin{array}{r}\text { post- } \\
\text { shock }\end{array}$ & 2011 & $\begin{array}{r}\text { post- } \\
\text { shock }\end{array}$ \\
\hline \multicolumn{9}{|l|}{ Real Estate Price Risk } \\
\hline CAR & 11.8 & 7.9 & 11.7 & 7.3 & 11.5 & 9.1 & 12.3 & 9.0 \\
\hline Capital shortfall (in $€ m$ ) & 0.0 & -552 & 0 & -483 & 0 & -14 & 0 & -55 \\
\hline Core Tier 1 ratio & 8.7 & 4.7 & 7.9 & 3.3 & 8.9 & 6.4 & 10.7 & 7.4 \\
\hline Core Tier 1 shortfall (in $€ \mathrm{~m}$ ) & -540 & $-1,945$ & -523 & $-1,610$ & -14 & -97 & -3 & -238 \\
\hline \multicolumn{9}{|l|}{ Concentration Risk } \\
\hline CAR & 11.8 & 9.8 & 11.7 & 9.8 & 11.5 & 10.1 & 12.3 & 9.8 \\
\hline Capital shortfall (in € m) & 0 & -25 & 0 & 0 & 0 & 0 & 0 & -25 \\
\hline Core Tier 1 ratio & 8.7 & 6.7 & 7.9 & 6.0 & 8.9 & 7.4 & 10.7 & 8.3 \\
\hline Core Tier 1 shortfall (in $€ \mathrm{~m}$ ) & -539 & $-1,177$ & -523 & -980 & -12 & -88 & -3 & -109 \\
\hline \multicolumn{9}{|l|}{ Liquidity Risk (Bottom-Up) } \\
\hline \multicolumn{9}{|l|}{ (in € m) } \\
\hline Total liabilities & 48,390 & 48,231 & 30,533 & 30,424 & 4,450 & 4,423 & 13,407 & 13,384 \\
\hline - of which liabilities to CB & 1,709 & 3,720 & 1,036 & 1,831 & 263 & 264 & 410 & 1,626 \\
\hline - of which liabilities to foreign banks & 9,459 & 6,532 & 4,239 & 2,983 & 60 & 14 & 5,160 & 3,534 \\
\hline Deficit of eligible financial assets & 0 & -643 & 0 & -110 & 0 & 0 & 0 & -533 \\
\hline \multicolumn{9}{|l|}{ Liquidity Risk (Top-Down) } \\
\hline Loans to non-banking sectors (in $€ \mathrm{~m}$ ) & 32,970 & 29,178 & 18,449 & 17,047 & 2,595 & 2,561 & 11,926 & 9,577 \\
\hline Change & & -11.5 & & -7.6 & & -1.3 & & -19.7 \\
\hline Effect on bank profits (in $€ \mathrm{~m}$ ) & & -122 & & -60 & & -2 & & -60 \\
\hline
\end{tabular}

Source: Bank of Slovenia 
Figure 1. Slovenia: Selected Banking Sector Indicators

Credit to the private sector declined in 2011 reflecting started banks' deleveraging, while NPLs continued to rise...
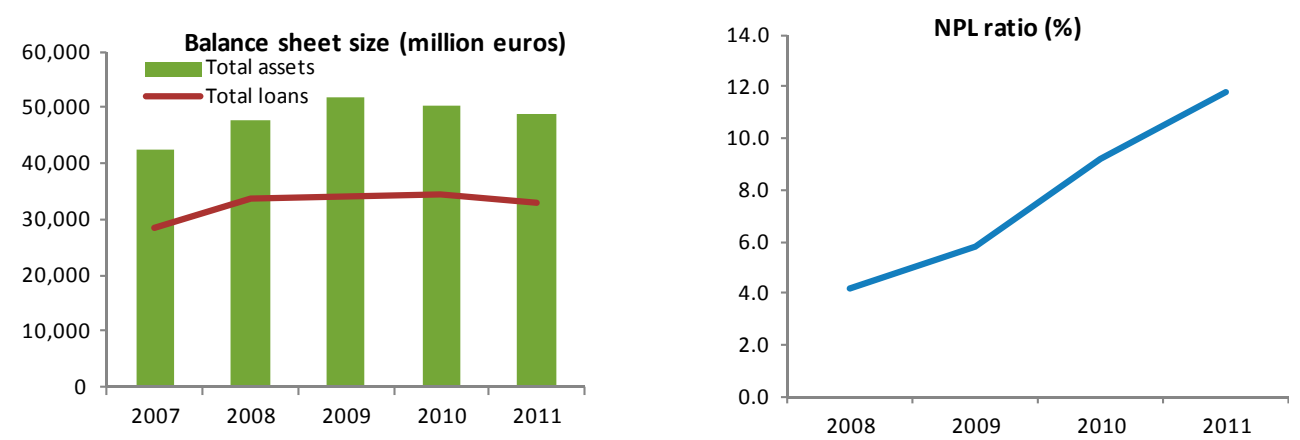

...resulting in increased loan loss provisioning, which in addition to decreased net interest income, in turn led to substantial bank losses...
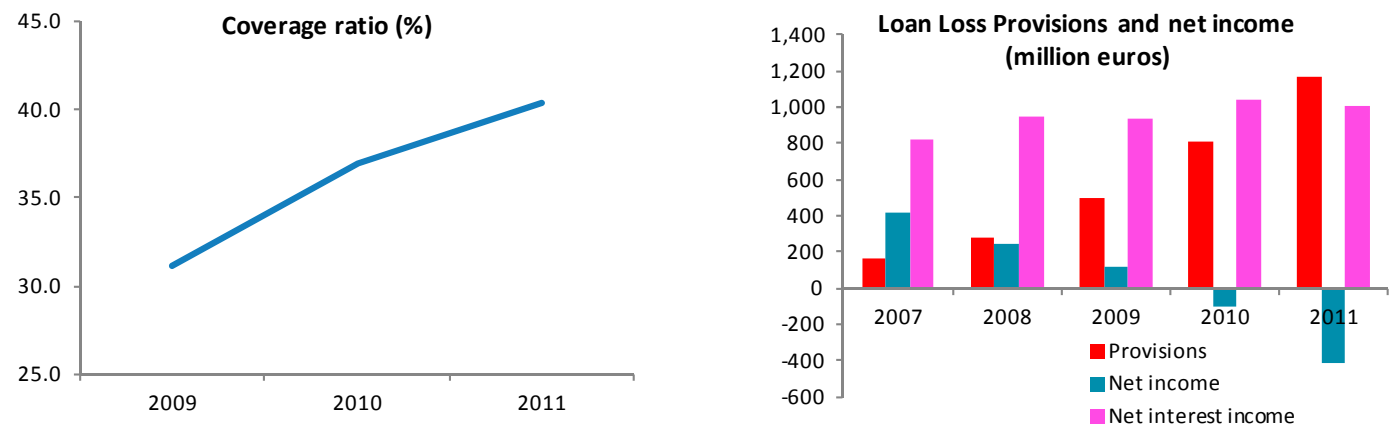

...Nevertheless, capital adequacy improved following fresh capital injections and banks' deleveraging and divestments of none core activities, while dependence on wholesale funding subsided owing to challenging capital markets.
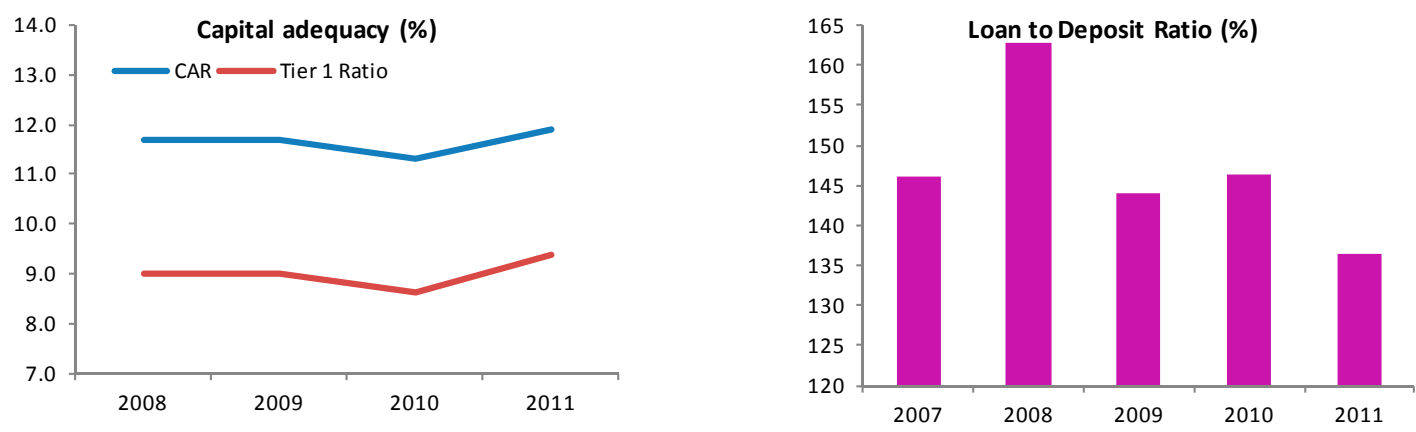

Source: Bank of Slovenia 


\section{APPEndix I. Slovenia: Status OF THE MAin Recommendations OF THE 2003 FSAP}

\begin{tabular}{l|l}
\hline Recommendations & Status \\
\hline \multirow{2}{*}{$\begin{array}{l}\text { Overall Supervisory Framework } \\
\text { Promote greater cooperation among the three supervisory agencies } \\
\text { (covering banking, insurance, and securities market) and appoint a } \\
\text { lead supervisor for financial conglomerates. }\end{array}$} & \\
\cline { 2 - 2 } $\begin{array}{l}\text { Revisit the conditions for deciding on which supervisory model to } \\
\text { adopt (a single regulatory agency or a sectoral approach) after EU } \\
\text { accession. }\end{array}$ & Ongoing \\
\hline $\begin{array}{l}\text { Establish proper arrangements for risk based cross sector } \\
\text { supervision. }\end{array}$ & Ongoing \\
\hline $\begin{array}{l}\text { Banking Supervision } \\
\text { Increase the risk focus of banking supervision. Supervisors must } \\
\text { acquire the capacity to assess how banks measure and quantify risks } \\
\text { in order to foster appropriate pricing of risk and provisioning. }\end{array}$ & Done \\
\hline $\begin{array}{l}\text { Strengthen supervisory capacity for consolidated supervision and } \\
\text { better monitoring risk transfer and connected lending. }\end{array}$ & Ongoing \\
\hline Considerably expand supervisory resources. & Ongoing \\
\hline $\begin{array}{l}\text { Insurance Supervision } \\
\text { Strengthen the independence of the AZN in terms of its governance } \\
\text { structure and the use of its budget }\end{array}$ & Not implemented \\
\hline $\begin{array}{l}\text { Develop technical skills of AZN staff to manage the critical prudential } \\
\text { issues that are facing the insurance sector. }\end{array}$ & Done \\
\hline $\begin{array}{l}\text { Provide responsible AZN officers with indemnity or insurance } \\
\text { protection against legal actions taken against them for activities } \\
\text { carried out as part of their duties. }\end{array}$ & Not implemented \\
\hline
\end{tabular}




\section{APPENDIX II. SLOVENIA: RISK ASSESSMENT MATRIX}

\begin{tabular}{|c|c|c|}
\hline $\begin{array}{l}\text { Nature/Source of } \\
\text { Main Threats and } \\
\text { Possible Triggers }\end{array}$ & $\begin{array}{l}\text { Likelihood of Severe Realization of } \\
\text { Threat in the Next } 3 \text { Years }\end{array}$ & $\begin{array}{c}\text { Expected Impact on Financial Stability if } \\
\text { Threat is Realized }\end{array}$ \\
\hline $\begin{array}{l}\text { More severe double- } \\
\text { dip recession, } \\
\text { triggered by a strong } \\
\text { intensification of the } \\
\text { euro area crisis }\end{array}$ & $\begin{array}{l}\text { Medium } \\
\text { - Global economic conditions remain } \\
\text { highly uncertain, to a large part due to } \\
\text { the continuing crisis in the euro area. } \\
\text { - Slovenia's sovereign ratings were } \\
\text { downgraded and remain on negative } \\
\text { watch. Sovereign bond spreads rose } \\
\text { sharply in late } 2011 \text { and remain } \\
\text { elevated, likely reflecting both contagion } \\
\text { and uncertainty with regard to Slovenia's } \\
\text { fiscal position, despite a relatively } \\
\text { prudent public debt position so far. }\end{array}$ & $\begin{array}{l}\text { High } \\
\text { - Slovenia's open economy means effects } \\
\text { through trade and financial channels, both } \\
\text { of which would have an impact on financial } \\
\text { stability. } \\
\text { - The largest bank was already required to } \\
\text { recapitalize by } € 320 \text { million by June } 2012 \text {. } \\
\text { Additional stress from a severe double dip } \\
\text { recession would likely increase this } \\
\text { recapitalization need, and could also raise } \\
\text { fiscal contingent liabilities. } \\
\text { - The bank's weak financial position could } \\
\text { also negatively impact the bank's } \\
\text { subsidiaries in neighboring countries, some } \\
\text { of which are of systemic importance in } \\
\text { those countries. The impact would likely be } \\
\text { through deleveraging. }\end{array}$ \\
\hline $\begin{array}{l}\text { Risk of a sharp } \\
\text { deleveraging unless } \\
\text { capital positions are } \\
\text { shored up }\end{array}$ & $\begin{array}{l}\text { Medium } \\
\text { - The ECB's 3-year LTRO has helped } \\
\text { alleviate pressures from refinancing } \\
\text { needs overall. However, the underlying } \\
\text { weakness remains and balance sheet } \\
\text { structures require further adjustment } \\
\text { toward more stable sources of funding. }\end{array}$ & $\begin{array}{l}\text { Medium } \\
\text { - In this context, if banks cannot shore up } \\
\text { their capital positions through fresh capital } \\
\text { injections, sharper deleveraging is likely to } \\
\text { take place and could mean a credit crunch } \\
\text { in Slovenia, which would impact negatively } \\
\text { on macroeconomic activity and eventually } \\
\text { feedback adversely to financial stability. }\end{array}$ \\
\hline $\begin{array}{l}\text { Sustained period of } \\
\text { slow growth }\end{array}$ & $\begin{array}{l}\text { Medium } \\
\text { - The banking system continues to make } \\
\text { losses and capital and liquidity buffers } \\
\text { are being eroded. The restructuring of } \\
\text { banks' sources of funding may also } \\
\text { increase the cost of funding and depress } \\
\text { margins. }\end{array}$ & $\begin{array}{l}\text { High } \\
\text { - Slow growth will not likely allow internal } \\
\text { capital generation. Loss-making } \\
\text { undercapitalized banks will not be able to } \\
\text { effectively support economic growth. Low } \\
\text { economic growth, in turn, could have } \\
\text { adverse feedback effects on financial } \\
\text { stability. }\end{array}$ \\
\hline $\begin{array}{l}\text { Sharp decline in real } \\
\text { estate prices }\end{array}$ & $\begin{array}{l}\text { Medium } \\
\text { - Such a decline could be triggered by } \\
\text { deteriorating economic and financial } \\
\text { conditions as above. }\end{array}$ & $\begin{array}{l}\text { High } \\
\text { - Real estate prices have declined only } \\
\text { moderately so far. Sharp declines would } \\
\text { imply further losses for banks. }\end{array}$ \\
\hline
\end{tabular}


APPendix III. Slovenia: Stress Testing MatriceS

Stress Test Matrix for the Banking Sector: Solvency Risk

\begin{tabular}{|c|c|c|}
\hline \multirow[t]{2}{*}{ Domain } & \multicolumn{2}{|c|}{ Assumptions } \\
\hline & Bottom-Up by Banks & Top-Down by Authorities \\
\hline Institutions included & - All & - All \\
\hline Market share & - 100 percent. & - 100 percent. \\
\hline Data and baseline date & $\begin{array}{l}\text { - Audited consolidated financial } \\
\text { statements as of December } \\
2011 \text {. }\end{array}$ & $\begin{array}{l}\text { - Audited unconsolidated } \\
\text { financial statements as of } \\
\text { December } 2011 .\end{array}$ \\
\hline Methodology & - Banks' internal models & - BOS model \\
\hline Stress test horizon & - 2 years & - 2 years \\
\hline Shocks & \multicolumn{2}{|c|}{$\begin{array}{l}\text { Scenario analysis } \\
\text { - Baseline: most recent BOS projections } \\
\text { - Scenario 1: double-dip adverse scenario (2 standard deviations for } \\
\text { GDP growth) } \\
\text { - Scenario 2: Slow growth scenario. } \\
\text { Sensitivity analysis } \\
\text { - Drop in the credit ratings of three largest exposures } \\
\text { - Decline in residential real estate prices by } 15 \text { percent } \\
\text { - Decline in commercial real estate prices by } 25 \text { percent }\end{array}$} \\
\hline Impact & $\begin{array}{l}\text { - Loan losses, sovereign bond } \\
\text { losses, net income, and capital } \\
\text { adequacy. }\end{array}$ & $\begin{array}{l}\text { - Loan losses, sovereign bond } \\
\text { losses, net income, and } \\
\text { capital adequacy. }\end{array}$ \\
\hline Calibration of risk parameters & $\begin{array}{l}\text { - Historical evidence } \\
\text { - BOS satellite model }\end{array}$ & $\begin{array}{l}\text { - Historical evidence } \\
\text { - BOS satellite model }\end{array}$ \\
\hline Behavioral adjustments & $\begin{array}{l}\text { - Zero-growth balance sheet } \\
\text { - Zero-payout ratio }\end{array}$ & $\begin{array}{l}\text { - Zero-growth balance sheet } \\
\text { - Zero-payout ratio }\end{array}$ \\
\hline Regulatory standards & $\begin{array}{l}\text { - Basel II } \\
\text { Hurdle rates: } \\
\text { - } 8 \text { percent regulatory CAR } \\
\text { (prudential minimum) } \\
\text { - } 9 \text { percent core Tier } 1 \text { capital } \\
\text { ratio (EBA requirement) }\end{array}$ & $\begin{array}{l}\text { - Basel II } \\
\text { Hurdle rates: } \\
\text { - } 8 \text { percent regulatory CAR } \\
\text { (prudential minimum) } \\
\text { - } 9 \text { percent core Tier } 1 \text { capital } \\
\text { ratio (EBA requirement) }\end{array}$ \\
\hline Results & $\begin{array}{l}\text { Scenario analysis } \\
\text { - Core Tier } 1 \text { and CAR shortfall in } \\
\text { nominal terms } \\
\text { Sensitivity analysis } \\
\text { - Core Tier } 1 \text { and CAR shortfall in } \\
\text { nominal terms }\end{array}$ & $\begin{array}{l}\text { Scenario analysis } \\
\text { - Core Tier } 1 \text { and CAR shortfall } \\
\text { in nominal terms } \\
\text { Sensitivity analysis } \\
\text { - Core Tier } 1 \text { and CAR shortfall } \\
\text { in nominal terms }\end{array}$ \\
\hline
\end{tabular}


Stress Test Matrix for the Banking Sector: Liquidity Risk

\begin{tabular}{|c|c|c|}
\hline \multirow[t]{2}{*}{ Domain } & \multicolumn{2}{|c|}{ Assumptions } \\
\hline & Bottom-Up by Banks & Top-Down by Authorities \\
\hline Institutions included & - All banks & - All banks. \\
\hline Market share & - 100 percent & - 100 percent. \\
\hline Data and baseline date & $\begin{array}{l}\text { - Audited financial statements as } \\
\text { of December } 2011 \text {. }\end{array}$ & $\begin{array}{l}\text { - Audited financial statements } \\
\text { as of December } 2011 \text {. }\end{array}$ \\
\hline Methodology & $\begin{array}{l}\text { A partial roll-over in maturing } \\
\text { wholesale funding, and a one- } \\
\text { notch downgrade of Slovenia's } \\
\text { sovereign rating }\end{array}$ & $\begin{array}{l}\text { - No roll-over in maturing } \\
\text { wholesale funding }\end{array}$ \\
\hline Risks & - Funding risk & - Funding risk \\
\hline Results & $\begin{array}{l}\text { - Liquidity shortfall to be financed } \\
\text { by ECB } \\
\text { - Adequacy of eligible collateral }\end{array}$ & $\begin{array}{l}\text { - Impact on deleveraging and } \\
\text { profitability }\end{array}$ \\
\hline
\end{tabular}




\section{AnNex I. Summary ObServance of the Basel Core Principles for EfFective BANKING SUPERVISION}

\section{A. Information and Methodology Used for the Assessment}

\section{The assessment of Basel Core Principles for Effective Banking Supervision} reflects the regulatory and supervisory frameworks in place as of the date of the completion of the assessment. The assessment was conducted in accordance with the Core Principles Methodology published in October 2006 by the Basel Committee on Banking Supervision. The assessment was based on (i) the legal and other documentary evidence; (ii) detailed interviews with staff from BOS and other authorities; and (iii) meetings with the banking industry as well as others such as academics and representatives of the accounting and audit profession. The assessors were Bruno Estecahandy (Banque de France) and Joel Shapiro (formerly of the U.S. Federal Reserve).

\section{B. Institutional and Macro-Prudential Setting and Market Structure}

60. Banks are the main financial institutions in Slovenia. Banks account for more than

75 percent of the total financial system assets, and government controlled banks dominate the system with a market share of around 55 percent in terms of assets or capital. Several foreign institutions have operations in Slovenia, mostly from France, Italy and Austria, but their overall market share is comparatively small. The overseas activities of Slovenian banks are located principally in other Balkan countries.

61. Financial supervision responsibilities in Slovenia are shared among several agencies. The Banking Supervision Department (BSD) of the BOS supervises banks. BOS is responsible also for payments system oversight. ATVP oversees the securities sector, while AZN mainly deals with the insurance sector.

62. Cooperation among the supervisory agencies occurs at various levels, from the top management level to more operational level. At the top management level, the MOF participates with the supervisory agencies on approaches to macro-relevant issues. At the operational level, cooperation between the three supervisory agencies appears productive and effective relative to planning for on-site examinations and routine supervisory issues. Cooperative efforts between the agencies are governed by a series of multilateral and bilateral MOUs.

63. The global crisis affected Slovenia's economy significantly, and most banks in the system were affected adversely by the economic downturn. The performance of banks deteriorated markedly as a result of higher levels of non-performing loans in the corporate and real estate sector, particularly construction industry. As a result, the banking system reported operating losses in both 2010 and 2011. Since a significant amount of asset growth prior to the economic crisis was fueled by wholesale funding from abroad, both capital adequacy and liquidity came under some strain. 
64. Strengthening the financial condition of the banking system is a key priority of the authorities at present. The 3-year LTROs have eased immediate liquidity pressures, but banks need to reduce dependence on wholesale funding and to restructure their balance sheets. Toward this end, a stronger capitalization of some banks would help avoid severe deleveraging and enable to provide credit to the economy. Further write-downs of nonperforming loans will have to be recognized in connection with bank restructuring. The operations of the government controlled banks will have to become more commercially oriented.

\section{Preconditions for Effective Banking Supervision}

65. Slovenia has a solid institutional framework supporting the conduct of sound macro-economic policies. Monetary policy is conducted by the BOS within the ESCB framework. Budgetary policy is conducted within a fiscal framework based on the requirements of the EU's Stability and Growth Pact. The recent financial crisis has put pressure on financial stability and the budgetary situation in Slovenia. Measures have been taken to ensure that the budget remains on a sustainable path. However, considerable adjustment still needs to be made.

66. The Slovenian legal framework for the financial sector is comprehensive and regularly updated. The EU's compendium of laws and regulations have been fully adopted and implemented relative to the financial sector. For banks, these are reflected in the major legislation affecting these institutions, including the Banking Act and attendant regulations, and the Companies Act.

67. Auditing and accounting rules applicable to financial institutions comply with international standards. All banks, insurance companies and listed companies have implemented IFRS. Disclosure and reporting requirements also are strict, and adhere to EU requirements as well.

68. The Slovenian legislative framework with regard to the audit profession requires internal and external auditors to be independent in both fact and appearance. The Banking Act requires the appointment of an internal auditor and an external auditor in a bank, and stipulates the governance of these auditors, who are subject to specific sections of the Audit Act relative to professional standards. The Agency for Public Oversight of Audit assures the independence of external auditors, including qualification requirements. The Agency also serves as a self-regulating body for the audit profession.

69. The judicial system, including that for bankruptcy and the enforcement of property rights, is well developed. However, the legal background and regulatory and institutional framework dealing with banks in a weak or deteriorating financial condition, as stipulated in the Banking Act, is inadequate. BOS needs a more effective set of bank resolution regulations and tools. 
70. BOS participates in the Trans European Automated Real-Time Gross Settlement Express Transfer 2 (TARGET2), the Real Time Gross Settlement of the Eurosystem. BOS operates the national component of TARGET2, which is the most important payment system in Slovenia. It enables the settlement of transactions between members of the system, and cross-border transactions with members of TARGET2 system outside Slovenia. The number and value accounted for by the latter are relatively small.

71. Financial reporting and disclosure requirements for financial institutions listed on capital market indices in Slovenia or other member states of the EU that operate in Slovenia are very strict. BOS requires detailed disclosures to the public in annual and quarterly financial statements, and in the management review (business report), the supervisory board's report, and statements or opinions from the directors, management or the external auditor.

72. The corporate governance of financial institutions in Slovenia is governed by the Companies Act and the Audit Act. In addition, sectoral legislation has been introduced to regulate the operation of each financial sector. For example, the Banking Act and accompanying regulations have provisions addressing corporate governance requirements for the banking system. Similar legislation addresses certain requirements in this regard for the insurance industry, the securities market and pension funds.

73. Slovenia has a deposit guaranty scheme that in effect insures depositors with funds on account in a bank aggregating $€ \mathbf{1 0 0 , 0 0 0}$. The scheme is administered by BOS, and can be utilized in the event a bank is declared bankrupt in accordance with current bankruptcy laws contained in the Banking Act. To date, the scheme has not been utilized.

74. The Slovenian legal framework for banking supervision is comprised principally of the Banking Act and attendant defining regulations. Other legislation of importance includes the Companies Act, the Conglomerates Act and the Audit Act, each of which contains provisions that round out and provide a comprehensive regulatory and supervisory structure. To implement prudential requirements, BOS employs defining regulations on specific areas ranging from capital adequacy to risk management practices.

\section{Main Findings ${ }^{20}$}

75. Objectives, independence, powers, transparency and cooperation (CP1): There is a generally comprehensive set of laws and regulations governing the supervision of the banking industry. BOS is autonomous both from a de jure and de facto perspective, although government policies and priorities act as an impediment to the robust supervision of the government controlled banks. The legal framework does not indemnify bank supervisors

\footnotetext{
${ }^{20}$ Annex Table 1 provides an overview of the assessment on a principle by principle basis.
} 
against damages resulting from the discharge of their responsibilities, nor does it provide protection against the costs of defending acts of commission or omission of their duties in good faith. Banking supervision is understaffed, and this problem could inhibit the ability of the BSD to achieve its mission and perform its responsibilities in a satisfactory manner.

76. Licensing and structure (CPs 2-5): The legal framework is clear relative to the types of banking and non-banking activities in which banks may engage. While there are few license applications, the legal framework, policies and processes are in place to evaluate the application of a bank license. The transfer of ownership is well defined in the law, and there are explicit definitions for controlling interests. The conditions for the acquisition of nonbank financial institutions are not contained in the law, and in fact, banks are permitted to acquire such institutions without regard to review or approval by BOS at present. The authorities are contemplating legislation to correct this gap in the legal framework.

77. Prudential regulation and requirements (CPs 6-18): The capital adequacy framework is based on international standards in accordance with EU directives. The entire Basel II regimen has been introduced into the legal framework in this manner. While BOS has established minimum capital requirements and has the capacity to require additional capital as warranted, the legal framework enables the shareholders of an institution to forestall the raising of additional capital. Virtually all major banking risks are subject to close scrutiny. The evaluation of risk management practices is generally adequate, but many banks have not yet fully developed satisfactory risk management systems in all aspects of their operations. Areas for improvement include certain aspects of credit risk management, particularly with respect to the reporting of problem assets and loan loss reserves. The reporting of problem assets lacks granularity, and the provisioning on NPLs stands at only 41 percent. As a result, there is a strong possibility that impaired assets are under-reserved. Other risks warranting some improvement include internal controls, liquidity risk, operational risks and monitoring of related parties exposures.

78. Methods of ongoing banking supervision (CPs19-21): BOS has implemented a risk-based approach to supervision. BSD has built a robust supervisory approach featuring a strong ICAAP-SREP program and Risk Assessment System (RAS) methodology. There also is a good mix of on-site and off-site supervision, with an extensive level of communication and cooperation between the two groups. There is an extensive set of reporting requirements for banks that provides a wide range of data and risk management information, both on a consolidated and unconsolidated basis. Appropriately, the information is used in the supervision process to evaluate risk and for other objectives. However, there are gaps in the information collected. Non-bank financial institutions are not required to file financial information on a solo basis, and the data collected on related parties is incomplete.

79. Accounting and disclosure (CP22): Disclosure requirements are very strict, and external auditors are employed to ensure that disclosure rules are adhered to. The auditing profession is held to high standards in law and practice by BOS, but it is self-regulating. BOS 
is not empowered to approve the external auditing firm that is retained by a bank. The banking system prepares its accounting records and reports financial information in accordance with IFRS.

80. Corrective and remedial powers (CP23): BOS has a satisfactory range of enforcement tools at its disposal to address supervisory issues. However, these may be impeded by shareholder rights relative to requirements to increase capital, and lack of power in the law to remove unqualified members of a supervisory board. The powers and strategies concerning the resolution of a problem bank are in need of strengthening.

\section{Consolidated and cross-border banking supervision (CPs24-25): BOS has} developed an overall satisfactory program of consolidated supervision. Supervisors are aware of the organizational structure of banking groups, have identified areas of risk, and maintain contact with other foreign bank supervisors and domestic authorities, principally through supervisory colleges. The program can be strengthened by focusing additional supervisory attention on non-bank financial companies, enhancing the understanding of related party interests throughout a banking group, and monitoring transactions with affiliated companies in a mixed activity company.

\section{Annex Table 1. Summary Compliance with the Basel Core Principles}

\begin{tabular}{|l|l|}
\hline \multicolumn{1}{|c|}{ Core Principle } & \multicolumn{1}{c|}{ Comments } \\
\hline $\begin{array}{l}\text { 1. Objectives, } \\
\text { independence, } \\
\text { powers, } \\
\text { transparency, and } \\
\text { cooperation }\end{array}$ & $\begin{array}{l}\text { The laws and regulations governing the supervision of the banking industry } \\
\text { are relatively comprehensive. The legal framework provides sufficient } \\
\text { supervisory tools to require banking corporations to comply with laws and } \\
\text { regulations, and there are adequate provisions in the law to facilitate } \\
\text { consolidated and cross-border supervision. Nevertheless, certain provisions of } \\
\text { the law should be strengthened or added to the regulatory framework to } \\
\text { enable BOS to respond in an appropriate manner. In particular, provisions in } \\
\text { the law need to be strengthened to enable the supervisors to prohibit } \\
\text { potentially unqualified candidates from being appointed to the supervisory } \\
\text { board, and to remove unqualified board members as well. The power to } \\
\text { require banks to raise capital should be made more effective and an } \\
\text { appropriate and effective bank resolution framework is necessary. }\end{array}$ \\
\hline $\begin{array}{l}\text { 1.1 Responsibilities } \\
\text { and objectives }\end{array}$ & $\begin{array}{l}\text { The set of laws and regulations is relatively comprehensive. BOS has clear } \\
\text { responsibility for banking supervision, and its powers in that regard are } \\
\text { stipulated in the Banking Act. To implement provisions of the Act, BOS has } \\
\text { issued regulations that complement and interpret provisions of the law. The } \\
\text { Banking Act has been amended several times since Slovenia's accession to } \\
\text { the EU to incorporate EBA guidelines. }\end{array}$ \\
\hline
\end{tabular}




\begin{tabular}{|c|c|}
\hline Core Principle & Comments \\
\hline $\begin{array}{l}1.2 \text { Independence, } \\
\text { accountability and } \\
\text { transparency }\end{array}$ & $\begin{array}{l}\text { BOS has a great deal of de jure and de facto independence and accountability } \\
\text { mechanisms are in place. No other government agency appears to influence } \\
\text { its decisions. However, the State's policies or priorities may act as an } \\
\text { impediment to the fully effective supervision of the Government controlled } \\
\text { banks. One such issue in this regard is the adequate capitalization of these } \\
\text { institutions. }\end{array}$ \\
\hline $\begin{array}{l}\text { 1.3 Legal } \\
\text { framework }\end{array}$ & $\begin{array}{l}\text { The Banking Act provides an overall satisfactory legal framework for the } \\
\text { supervision of banks, and is complemented with a compendium of detailed } \\
\text { regulations. Provisions of the law regarding the supervision of members of the } \\
\text { supervisory board, the requirement to raise capital and the tools to resolve a } \\
\text { problem bank should be strengthened. }\end{array}$ \\
\hline 1.4 Legal powers & $\begin{array}{l}\text { BOS has sufficient powers in the law, and an appropriate range of tools, to } \\
\text { require banks to comply with banking laws and regulations in most cases. } \\
\text { Bank shareholders can impede the supervisor's requirement to raise capital, } \\
\text { and the manner in which supervisors are authorized to deal with unqualified } \\
\text { members of the supervisory board must be strengthened. }\end{array}$ \\
\hline 1.5 Legal protection & $\begin{array}{l}\text { Protections in the law to indemnify bank supervisors against litigation in the } \\
\text { proper conduct and execution of their responsibilities as bank supervisors are } \\
\text { inadequate. }\end{array}$ \\
\hline 1.6 Cooperation & $\begin{array}{l}\text { A satisfactory framework for cooperation on supervisory issues and the } \\
\text { exchange of information exists between BOS and other financial regulators } \\
\text { both in Slovenia and abroad. Cooperative efforts and the exchange of } \\
\text { information with other Slovenian financial regulators are maturing, as reflected } \\
\text { in the establishment of interagency committees. Such efforts with foreign bank } \\
\text { supervisors have a longer history and have been carried out successfully. }\end{array}$ \\
\hline $\begin{array}{l}\text { 2. Permissible } \\
\text { activities }\end{array}$ & $\begin{array}{l}\text { The legal framework is clear relative to the use of the word "bank" and the } \\
\text { types of banking and non-banking financial activities in which banking groups } \\
\text { may engage. }\end{array}$ \\
\hline 3. Licensing criteria & $\begin{array}{l}\text { The infrastructure is in place in terms of the legal framework, policies and } \\
\text { processes to evaluate licensing applications, and the program is effective. } \\
\text { However, BOS lacks the power to evaluate and license members of the } \\
\text { supervisory board. }\end{array}$ \\
\hline $\begin{array}{l}\text { 4. Transfer of } \\
\text { significant } \\
\text { ownership }\end{array}$ & $\begin{array}{l}\text { The transfer of ownership is well defined in the law, and there are explicit } \\
\text { definitions for qualifying holders. However, the sanctions applied to qualifying } \\
\text { holders who obtain their ownership interest in a bank without authorization of } \\
\text { BOS are weak. Banks are not required to inform BOS of a material adverse } \\
\text { event that would affect the suitability of a qualifying holder. }\end{array}$ \\
\hline $\begin{array}{l}5 . \text { Major } \\
\text { acquisitions }\end{array}$ & $\begin{array}{l}\text { BOS does not authorize the establishment of non-bank financial companies for } \\
\text { Slovenian banks. Slovenian banks are free to acquire such companies in } \\
\text { Slovenia or the EU without authorization and an evaluation of the financial } \\
\text { capacity of the bank to acquire such an organization, or its plans relative to the } \\
\text { establishment of appropriate risk management practices in the company. }\end{array}$ \\
\hline
\end{tabular}




\begin{tabular}{|c|c|}
\hline Core Principle & Comments \\
\hline 6. Capital adequacy & $\begin{array}{l}\text { The regulatory framework for capital adequacy is aligned with the } \\
\text { amendments to the Basel international standards, and the supervisors are } \\
\text { proactively preparing for the implementation of Basel III. BOS's authority in } \\
\text { requiring banks to increase capital is clear, but there are provisions in the law } \\
\text { that enables a bank's shareholders to frustrate the supervisor's efforts in this } \\
\text { regard. The supervisors are not aggressively requiring banks to increase } \\
\text { capital based on the results of the ICAAP/SREP process, or moving banks to } \\
\text { employ more enhanced capital measurement techniques, such as internal } \\
\text { ratings-based (IRB) approach relative to credit risk. The supervisors prefer to } \\
\text { require banks to improve their risk management practices. While this is } \\
\text { commendable, it is not a substitute for adequate capitalization. Employment of } \\
\text { enhanced techniques is expected to result in capital shortfalls for many banks. } \\
\text { With respect to the Government controlled institutions. BOS's powers to } \\
\text { ensure that additional capital is raised are limited. }\end{array}$ \\
\hline $\begin{array}{l}\text { 7. Risk } \\
\text { management } \\
\text { process }\end{array}$ & $\begin{array}{l}\text { The internal RAS/POT methodology for off-site and on-site supervision } \\
\text { provides BOS examiners and analysts with generally adequate guidance for } \\
\text { assessing a bank's risk management process. However the regulatory } \\
\text { guidance on banks internal control framework and on risk control functions } \\
\text { organisation, missions and resources could be more precise and prescriptive. } \\
\text { BOS duly made use of its power to require banks to strengthen their risk } \\
\text { management process and culture but has not been fully successful in } \\
\text { obtaining the expected improvements in a timely manner. }\end{array}$ \\
\hline 8. Credit risk & $\begin{array}{l}\text { The regulatory framework on credit risk is relevant as well as is the guidance } \\
\text { given to the on-site or off-site examiners/analysts in the internal part of BOS's } \\
\text { RAS/POT methodology. Credit risk is well identified by the BOS as the } \\
\text { prominent risk in the Slovenian banking system. However the Supervisor's } \\
\text { ability to keep under control banks credit policies and practices has not been } \\
\text { demonstrated taking into account the rise in NPLs and their impact at present } \\
\text { on bank profitability. Moreover there is some evidence that credit risk might } \\
\text { have been underestimated and that at least some banks have not followed a } \\
\text { prudent approach to the degree that was suggested by the supervisor during } \\
\text { the years of prosperity supported by high lending growth. The number of } \\
\text { banks using the foundation IRB approach is very limited and the ones who use } \\
\text { it are not the country's biggest credit institutions. Banks have indeed few } \\
\text { incentives to shift to IRB in the absence of a regulatory constraint to use it and } \\
\text { since it would very likely result in additional capital requirements. }\end{array}$ \\
\hline $\begin{array}{l}\text { 9. Problem assets, } \\
\text { provisions, and } \\
\text { reserves }\end{array}$ & $\begin{array}{l}\text { Banks report monthly on exposures to debtors using a } 5 \text { grade classification } \\
\text { system. This regulatory reporting provides the supervisor with valuable data } \\
\text { on credit risk and is a useful tool for conducting macro-prudential surveys. } \\
\text { However the credit classification lacks of granularity and the intermediate } \\
\text { class C, which accounts for about } 10 \text { percent of the classified assets, is not } \\
\text { homogenous. Impairment on NPLs is only } 40 \text { percent which is rather low by } \\
\text { any standard, including BOS's Individual Capital Adequacy Standards } \\
\text { methodology for evaluating expected losses (53 percent), which reflects in part } \\
\text { the need for greater granularity. }\end{array}$ \\
\hline
\end{tabular}




\begin{tabular}{|c|c|}
\hline Core Principle & Comments \\
\hline $\begin{array}{l}\text { 10. Large exposure } \\
\text { limits }\end{array}$ & $\begin{array}{l}\text { BOS is compliant with BCBS and EU guidelines on large exposure limits and } \\
\text { on the definition of connected counterparties. BOS's on-site examiners as well } \\
\text { as off-site analysts perform regularly controls to make sure that banks comply } \\
\text { with large exposure rules. Furthermore BOS monitors concentration risks and } \\
\text { requires that banks put in place limits to concentration risks. In particular BOS } \\
\text { has defined measurement methodologies for sectoral risk that banks must } \\
\text { comply with. However supervisor's action to prevent sectoral concentration } \\
\text { risk to emerge as a major issue has not been fully successful. Many banks } \\
\text { indeed have high exposure on the construction and housing sector and on the } \\
\text { financial intermediation sector. }\end{array}$ \\
\hline $\begin{array}{l}\text { 11. Exposure to } \\
\text { related parties }\end{array}$ & $\begin{array}{l}\text { Law and regulations provide a comprehensive definition of related parties and } \\
\text { provides regulatory basis for preventing abuses arising from exposures to } \\
\text { related party and for addressing conflicts of interest. Furthermore BOS } \\
\text { requires from banks quarterly reports on large exposures and annually for } \\
\text { related parties and assesses these reports as a part of off-site supervision. } \\
\text { However, related party exposures are not gauged adequately on a } \\
\text { consolidated basis through the supervisory returns process or by other means. } \\
\text { It is as much a matter of concern that the small size and structure of the } \\
\text { Slovenian economy itself induces multiple interrelations between firms. }\end{array}$ \\
\hline $\begin{array}{l}\text { 12. Country and } \\
\text { transfer risks }\end{array}$ & $\begin{array}{l}\text { No specific rules for country and transfer risk are determined in Slovenian } \\
\text { legislation or regulations. Nevertheless the RAS/POT methodology provides } \\
\text { BOS's examiners and analysts with some useful guidance. Moreover banks } \\
\text { must report monthly to the BOS on their overall country exposure. This light } \\
\text { framework is proportionate to the issue as banks foreign countries exposure is } \\
\text { limited. }\end{array}$ \\
\hline 13. Market risks & $\begin{array}{l}\text { BOS regulatory prescriptions in the market risk field sometimes lacks precision } \\
\text { or stringency but BOS's RAS/POT methodology gives more guidance to } \\
\text { supervisor's examiners and indirectly to banks. Furthermore, market activities } \\
\text { of banks are in most cases very limited and receding. Thus capital } \\
\text { requirement for market risk is only } 2 \text { percent of the overall capital needs } \\
\text { according to ICAAP/SREP estimates. In such a context, regulatory } \\
\text { environment and BOS's supervisory practices can be regarded as adequate. }\end{array}$ \\
\hline 14. Liquidity risk & $\begin{array}{l}\text { BOS has set a comprehensive and pertinent liquidity risk supervision } \\
\text { framework, both qualitative and quantitative. It encompasses daily banks } \\
\text { reporting on liquidity ratio and the compliance with a liquidity ratio. As liquidity } \\
\text { strains in European markets were continuing BOS opportunely encouraged } \\
\text { banks to deleverage, to sell assets when possible and to make a large use of } \\
\text { ECB facilities, including } 3 \text { years LTRO. However, like in many other countries, } \\
\text { funding issues were not given timely and sufficient attention by banks and by } \\
\text { the Supervisor in advance of the crisis. }\end{array}$ \\
\hline
\end{tabular}




\begin{tabular}{|c|c|}
\hline Core Principle & Comments \\
\hline 15. Operational risk & $\begin{array}{l}\text { BOS's operational risk (OR) reporting requirements are aligned with Common } \\
\text { Repository (COREP) reporting requirement on loss events. Collection of } \\
\text { aggregate loss event data is required on a quarterly basis. Collection of loss } \\
\text { event details is on request only. Off-site investigations have been limited in } \\
\text { number and depth due to the lack of skilled human resources; it is not } \\
\text { apparent that the Supervisor has put enough emphasis on this category of } \\
\text { risk. Moreover BOS may have not paid adequate attention to some specific } \\
\text { OR the Slovenian banking industry is exposed to, such as OR linked to market } \\
\text { activities, (rogue trading); and suitability in trading activities like CHF } \\
\text { denominated loans. Even if such types of OR have not materialized to date } \\
\text { they shouldn't be considered negligible. However there is no evidence that OR } \\
\text { is not adequately covered by capital (OR accounts for } 15 \text { percent of the capital } \\
\text { needs according to ICAAP and SREP). }\end{array}$ \\
\hline $\begin{array}{l}\text { 16. Interest-rate } \\
\text { risk in the banking } \\
\text { book }\end{array}$ & $\begin{array}{l}\text { BOS's regulatory requirements are not very specific on different aspects of the } \\
\text { interest rate risk management, including assumptions and stress-tests. In such } \\
\text { an environment it does not seem that Slovenian banks have implemented } \\
\text { sophisticated methodologies and a large variety of scenarios for measuring } \\
\text { impact of interest rate, basis and spreads changes on their banking book. } \\
\text { However the need for comprehensive and sophisticated methodologies is } \\
\text { limited as the balance sheet structure of Slovenian banks does not reflect very } \\
\text { significant interest rate exposure. Indeed a large portion of loans to corporate } \\
\text { or households including mortgages are granted with variable rates while most } \\
\text { liabilities are also indexed on BOR indices. Further disclosure by banks on } \\
\text { ALM issues would be desirable nevertheless. }\end{array}$ \\
\hline $\begin{array}{l}\text { 17. Internal control } \\
\text { and audit }\end{array}$ & $\begin{array}{l}\text { The Banking Law and BOS regulations set general principles as regards the } \\
\text { banks' internal control framework. Going further the RAS/POT methodology } \\
\text { provides the banks with some more guidance on the Supervisor's expectations } \\
\text { and offers to BOS examiners a more comprehensive toolkit for assessing } \\
\text { banks' internal controls and the internal audit function. However the credit risk } \\
\text { problems and the liquidity strains that the Slovenian banking system is now } \\
\text { facing cast some doubt on the adequacy of banks' internal controls and on the } \\
\text { skills and/or independence of the control functions including the internal audit). } \\
\text { It also tends to demonstrate that even if the Supervisor is now very active in } \\
\text { prescribing remedial, correcting measures it may have not been in the recent } \\
\text { past proactive enough in this regard and/or unable to enforce in a timely } \\
\text { manner the prescribed improvements in banks internal controls. }\end{array}$ \\
\hline $\begin{array}{l}\text { 18. Abuse of } \\
\text { financial services }\end{array}$ & $\begin{array}{l}\text { Slovenian law and regulations as well as the BOS's "Guidance for the } \\
\text { implementation of measures regarding the prevention of money laundering } \\
\text { and terrorist financing for the banking sector" have set the legal framework for } \\
\text { promoting high ethical standards and preventing the banks from being used } \\
\text { for criminal activities. However, as already noticed in the March } 2012 \\
\text { MONEYVAL follow-up report, the efficiency of this framework is in practice } \\
\text { hampered by two major shortcomings: (i) the relatively low number and } \\
\text { severity of administrative sanctions, and (ii) the still inadequate on-site } \\
\text { examination resources devoted to AML/CFT. }\end{array}$ \\
\hline
\end{tabular}




\begin{tabular}{|c|c|}
\hline Core Principle & Comments \\
\hline $\begin{array}{l}\text { 19. Supervisory } \\
\text { approach }\end{array}$ & $\begin{array}{l}\text { BOS has implemented a risk-based approach to supervision. Through SREP- } \\
\text { ICAAP dialog, RAS/POT methodology and some other tools (e.g., ICAS) BOS } \\
\text { has built a robust and well designed supervisory approach. Moreover BOS can } \\
\text { also rely on the high quality of its supervisory staff for understanding the } \\
\text { operations and for assessing the individual banks' risk. Nevertheless the crisis } \\
\text { revealed some serious weaknesses in the past approach and implementation } \\
\text { practices of the BOS. It appears quite obvious that the Supervisor has been } \\
\text { overconfident in the banks' ability to master and command their risks and has } \\
\text { failed to identify or to address in a timely manner the development of a credit } \\
\text { bubble, the rise of sectoral concentration risks and the dependence of } \\
\text { Slovenian banks to foreign wholesale funding. Then there is a strong need for } \\
\text { more in-depth reviews and ongoing monitoring by the off-site supervision and } \\
\text { overall for a more forward looking, a more proactive rather than reactive } \\
\text { approach and a somewhat more intensive and demanding implementation of } \\
\text { banking supervision. }\end{array}$ \\
\hline $\begin{array}{l}\text { 20. Supervisory } \\
\text { techniques }\end{array}$ & $\begin{array}{l}\text { There is a good mix of on-site and off-site supervision, with a high level of } \\
\text { communication and cooperation between the two groups. Whereas } \\
\text { supervisory resources have been expanded by } 25 \% \text { globally since the last } \\
\text { FSAP in } 2003 \text { the off-site supervision section is still understaffed. A significant } \\
\text { increase in resources would allow the off-site section to developed meetings } \\
\text { with the banks both at the higher level and at more operational level. It would } \\
\text { also permit the staff to better capitalize on the results of banks' internal audit } \\
\text { functions whose reports are not yet systematically used and evaluated. An } \\
\text { increase in the off-site staff along with targeted hiring of on-site resources } \\
\text { (which presently is short on AML/CFT, IT and OR experts), and better } \\
\text { leveraging of internal controls and audits would result in a more proactive, } \\
\text { more intensive, more forward looking and hopefully more efficient banking } \\
\text { supervision. }\end{array}$ \\
\hline $\begin{array}{l}\text { 21. Supervisory } \\
\text { reporting }\end{array}$ & $\begin{array}{l}\text { BOS receives an abundance of information from banks that the supervisors } \\
\text { utilize in ongoing supervision. There are, nevertheless, gaps in the data } \\
\text { collected. Non-bank financial companies are not required to file information on } \\
\text { a solo basis, and the data collected on related party transactions is } \\
\text { incomplete. }\end{array}$ \\
\hline $\begin{array}{l}\text { 22. Accounting and } \\
\text { disclosure }\end{array}$ & $\begin{array}{l}\text { Disclosure requirements are very strict, and external auditors are employed to } \\
\text { ensure that disclosure rules are adhered to. Banks are required to account for } \\
\text { and report financial information in accordance with IFRS. Auditing firms are } \\
\text { licensed by a public agency and are held to international best practice in their } \\
\text { professionalism and expertise. }\end{array}$ \\
\hline $\begin{array}{l}\text { 23. Corrective and } \\
\text { remedial powers of } \\
\text { supervisors }\end{array}$ & $\begin{array}{l}\text { BOS has a satisfactory range of enforcement tools at its disposal to address } \\
\text { supervisory issues. However, these may be impeded by shareholder rights } \\
\text { relative to requirements to increase capital, and lack of power in the law to } \\
\text { remove unqualified members of a supervisory board. The powers and } \\
\text { strategies concerning the resolution of a problem bank are in need of } \\
\text { strengthening. }\end{array}$ \\
\hline
\end{tabular}




\begin{tabular}{|l|l|}
\hline \multicolumn{1}{|c|}{ Core Principle } & \multicolumn{1}{c|}{ Comments } \\
\hline $\begin{array}{l}\text { 24. Consolidated } \\
\text { supervision }\end{array}$ & $\begin{array}{l}\text { BOS has developed an overall satisfactory program of consolidated } \\
\text { supervision. Supervisors are aware of the organizational structure of banking } \\
\text { groups, have identified areas of risk, and maintain contact with other foreign } \\
\text { bank supervisors and domestic authorities, principally through supervisory } \\
\text { colleges. The program can be strengthened by focusing additional supervisory } \\
\text { attention on non-bank financial companies, enhancing the understanding of } \\
\text { related party interests throughout a banking group, monitoring transactions } \\
\text { with affiliated companies in a mixed activity company, and more aggressively } \\
\text { monitoring the results of supervisory actions imposed on subsidiaries. }\end{array}$ \\
\hline $\begin{array}{l}\text { 25. Home-host } \\
\text { relationships }\end{array}$ & $\begin{array}{l}\text { BOS engages in host-home country relationships commensurate with the size } \\
\text { and complexity of the operations of Slovenian banks operating abroad. Formal } \\
\text { written agreements governing cooperation and information exchange are in } \\
\text { effect between BOS and ten European bank supervisors. BOS participates in } \\
\text { several supervisory colleges, and acts as the coordinator of such colleges } \\
\text { relative to the foreign operations of two Slovenian banks. }\end{array}$ \\
\hline
\end{tabular}

\section{Recommended Action Plan}

82. Annex Table 2 summarizes the recommendations formulated in the course of the assessment.

\section{Annex Table 2. Recommended Action Plan to Improve Compliance with the Basel Core Principles}

\begin{tabular}{|l|l|}
\hline \multicolumn{1}{|c|}{$\begin{array}{c}\text { Reference } \\
\text { Principle }\end{array}$} & \multicolumn{1}{c|}{ Recommended Action } \\
\hline $\begin{array}{l}\text { 1 (2) Independence, } \\
\text { accountability and } \\
\text { transparency }\end{array}$ & $\begin{array}{l}\text { It is time to reassess the staffing needs of the Banking Supervision } \\
\text { Department. The implementation of the Risk Assessment System, monitoring } \\
\text { of industries systemic to the Slovenian economy, the challenges in fully } \\
\text { implementing operations risk and Basel III have all strained the Department's } \\
\text { resources. Optimally, the current ceiling on the number of professional staff } \\
\text { should be raised so that further staff additions can be made as appropriate. }\end{array}$ \\
\hline $\begin{array}{l}1 \text { (3) Legal } \\
\text { framework }\end{array}$ & $\begin{array}{l}\text { To further improve the comprehensiveness of banking laws and regulations, } \\
\text { provisions should be added or amended to the Banking Act. Such changes } \\
\text { should address the supervisor's power to license or remove supervisory board } \\
\text { members, the ability of shareholders to impede the supervisor's power to } \\
\text { require a capital increase, and the introduction of an appropriate bank } \\
\text { resolution regime. }\end{array}$ \\
\hline $\begin{array}{l}1 \text { (5) Legal } \\
\text { Protection }\end{array}$ & $\begin{array}{l}\text { Slovenian law should be amended to provide indemnification against legal } \\
\text { action for employees of BOS in the discharge of their duties and } \\
\text { responsibilities. }\end{array}$ \\
\hline
\end{tabular}




\begin{tabular}{|c|c|}
\hline $\begin{array}{l}\text { Reference } \\
\text { Principle }\end{array}$ & Recommended Action \\
\hline 1 (6) Cooperation & $\begin{array}{l}\text { The authorities should consider strengthening the communications link } \\
\text { between the Commission and the Coordinating (Steering) Committee. For } \\
\text { example, the Commission could provide the Coordinating Committee its views } \\
\text { relative to issues or supervisory concerns manifesting themselves in the } \\
\text { financial system. The Commission could establish ad hoc working groups with } \\
\text { representatives from each supervisory agency to propose policies or practices } \\
\text { that would be implemented in each agency. }\end{array}$ \\
\hline 3 Licensing activities & $\begin{array}{l}\text { A provision should be added to the Banking Law that would enable BOS to } \\
\text { license supervisory board members. With the weight of the prospective EBA } \\
\text { Guidelines on Internal Governance set to be introduced, it is an appropriate } \\
\text { time to introduce such legislation. }\end{array}$ \\
\hline $\begin{array}{l}\text { 4.Transfer of } \\
\text { significant ownership }\end{array}$ & $\begin{array}{l}\text { The sanctions applied to a qualifying holder in the event the shares in a bank } \\
\text { are acquired without gaining the approval of BOS should be strengthened. It } \\
\text { is recommended that, at a minimum, the qualifying holder should be restricted } \\
\text { from voting any shares, or prohibited from benefiting from other advantages of } \\
\text { ownership, such as receiving dividends or gaining the appreciation in the } \\
\text { market value of the shares. At present, qualifying holders who have acquired } \\
\text { their shares illegally are restricted from voting and receiving dividends and are } \\
\text { required to pay a penalty. }\end{array}$ \\
\hline 5. Major Acquisitions & $\begin{array}{l}\text { It is recommended that the authorities require banks to obtain a supervisory } \\
\text { approval prior to acquiring a non-bank financial company. The criteria applied } \\
\text { should be similar to acquiring a controlling interest in a bank. }\end{array}$ \\
\hline 6. Capital adequacy & $\begin{array}{l}\text { BOS should be empowered to require a bank to increase capital, as a special } \\
\text { capital charge or for other reasons, without potential impediments raised by the } \\
\text { bank's shareholders. Consideration should be given to requiring banks to } \\
\text { acquire additional capital based on the findings of the ICAAP/SREP process. } \\
\text { While requiring banks to improve their risk management practices is } \\
\text { commendable, and ultimately is the correct solution, this frequently is a more } \\
\text { protracted affair and is not a substitute for the appropriate level of capital that } \\
\text { is needed. In keeping with best practice, it should prod the larger systemically } \\
\text { important banks in the system towards gaining the expertise and employing } \\
\text { modeling techniques. Use of IRB for credit risk, for example, is expected to } \\
\text { reflect a need for capital contributions in these institutions. With the full } \\
\text { implementation of Basel III scheduled for January } 2013 \text {, the supervisors should } \\
\text { consider monitoring closely through required written capital plans or other } \\
\text { communications the manner in which banks plan to meet the capital adequacy } \\
\text { requirements, and the progress made toward this goal. }\end{array}$ \\
\hline $\begin{array}{l}\text { 7. Risk management } \\
\text { process }\end{array}$ & $\begin{array}{l}\text { Guidance to banks on internal control framework and on risk control functions } \\
\text { organisation, missions and resources should be more precise and prescriptive. } \\
\text { In particular the risk management function should have more power in the } \\
\text { decision making process. BOS should be more proactive in identifying risk } \\
\text { management issues and be more demanding that banks take remedial actions } \\
\text { in a timely manner. }\end{array}$ \\
\hline
\end{tabular}




\begin{tabular}{|c|c|}
\hline $\begin{array}{l}\text { Reference } \\
\text { Principle }\end{array}$ & Recommended Action \\
\hline 8. Credit risk & $\begin{array}{l}\text { The supervisor should intervene timely and forcefully when identifying a rise in } \\
\text { credit risk and should put more pressure on banks for classifying more } \\
\text { appropriately their claims on individual debtors and requiring additional } \\
\text { provisioning when needed even if it can result in a deteriorated capital ratio. } \\
\text { BOS should also encourage a wider use of IRB approaches. }\end{array}$ \\
\hline $\begin{array}{l}\text { 9. Problem assets, } \\
\text { provisions, and } \\
\text { reserves }\end{array}$ & $\begin{array}{l}\text { BOS should consider shifting to a more granular claims classification with more } \\
\text { homogenous credit categories. } \\
\text { It should encourage external auditors to review with a more critical bias the } \\
\text { banks' loan portfolios and require from banks to maintain or increase } \\
\text { accordingly their external audit budgeted/fees. It should develop on-site } \\
\text { examinations of loan portfolios on larger samples and induce the banks to take } \\
\text { a more conservative stance on collateral valuation. }\end{array}$ \\
\hline $\begin{array}{l}\text { 10. Large exposure } \\
\text { limits }\end{array}$ & $\begin{array}{l}\text { BOS should pay more attention to the development of sectoral concentration } \\
\text { risks and intervene on a more preemptively and in a more directive way as } \\
\text { soon as they are detected. }\end{array}$ \\
\hline $\begin{array}{l}\text { 11. Exposure to } \\
\text { related parties }\end{array}$ & $\begin{array}{l}\text { BOS should improve its internal RAS/POT methodology on this issue in } \\
\text { providing its examiners and analysts. }\end{array}$ \\
\hline $\begin{array}{l}\text { 12. Country and } \\
\text { transfer risk }\end{array}$ & $\begin{array}{l}\text { BOS should be ready to take a closer look on country risk exposure and its } \\
\text { adequate provisioning if and when it becomes a material risk. }\end{array}$ \\
\hline 13. Market risks & $\begin{array}{l}\text { BOS should stand ready for establishing more demanding requirements and } \\
\text { expectations in the market risk field if and when it becomes a material risk for } \\
\text { Slovenian banks. }\end{array}$ \\
\hline 14. Liquidity risk & $\begin{array}{l}\text { BOS should encourage domestic banks to reduce their dependence to external } \\
\text { borrowings and the wholesale market and should require them to reduce their } \\
\text { loan-to-deposit ratio by any available measure when needed. BOS should } \\
\text { encouraged banks to monitor closely their progress for being less dependent } \\
\text { of the Euro system's financing. }\end{array}$ \\
\hline 15. Operational risk & $\begin{array}{l}\text { BOS' OR reporting requirements should be enhanced and the number of on- } \\
\text { site investigations should be increased; on-site supervision expertise and } \\
\text { resources should be increased accordingly. } \\
\text { More emphasis should be put on some specific OR the Slovenian banking } \\
\text { industry is exposed to (e.g., OR linked to marked activities and suitability in } \\
\text { lending activities). }\end{array}$ \\
\hline $\begin{array}{l}\text { 16. Interest-rate risk } \\
\text { in the banking book }\end{array}$ & $\begin{array}{l}\text { BOS should be more specific as regards its expectations on different aspects } \\
\text { of the interest rate risk management including assumptions and should } \\
\text { encourage the largest banks to develop more sophisticated methodologies for } \\
\text { evaluating their interest rate risk on their banking book under normal } \\
\text { circumstances as well as in stressed circumstances. Further disclosure from } \\
\text { banks on ALM issues would also be desirable. }\end{array}$ \\
\hline
\end{tabular}




\begin{tabular}{|c|c|}
\hline $\begin{array}{l}\text { Reference } \\
\text { Principle }\end{array}$ & Recommended Action \\
\hline $\begin{array}{l}\text { 17. Internal control } \\
\text { and audit }\end{array}$ & $\begin{array}{l}\text { BOS should encourage banks to have a more powerful risk management } \\
\text { function. It should also monitor more closely, on an ongoing basis, the quality } \\
\text { and comprehensiveness of internal reports, including audit reports. BOS } \\
\text { should have has some licensing or veto power for the appointment to the } \\
\text { supervisory board and the audit committee. }\end{array}$ \\
\hline $\begin{array}{l}\text { 18. Abuse of } \\
\text { financial services }\end{array}$ & $\begin{array}{l}\text { BOS should increase the number and severity of administrative sanctions and } \\
\text { fines issued for AML/CFT non compliance. It also should consider that such } \\
\text { measures are made public. } \\
\text { BOS should increase significantly its on-site examination resources devoted to } \\
\text { AML/CFT so that it could increase the number of on-site inspections. }\end{array}$ \\
\hline $\begin{array}{l}\text { 19. Supervisory } \\
\text { approach }\end{array}$ & $\begin{array}{l}\text { There is a strong need for more in-depth reviews and ongoing monitoring by } \\
\text { off-site supervision (which will require additional staff) and overall for a more } \\
\text { forward looking, a more proactive rather than reactive approach and a } \\
\text { somewhat more intensive implementation of banking supervision. }\end{array}$ \\
\hline $\begin{array}{l}\text { 20. Supervisory } \\
\text { techniques }\end{array}$ & $\begin{array}{l}\text { Off-site staff and to a lesser extent on-site staff should be expanded. A } \\
\text { significant increase in resources would allow the off-site section to developed } \\
\text { meetings with the banks both at the higher level and at more operational level. } \\
\text { It would also permit staff to better capitalize on banks' internal audit function } \\
\text { production whose reports are not yet systematically used and evaluated. } \\
\text { Some more targeted hiring of on-site resource (which presently is short of IT } \\
\text { and OR experts), is also highly desirable. }\end{array}$ \\
\hline $\begin{array}{l}\text { 21. Supervisory } \\
\text { reporting }\end{array}$ & $\begin{array}{l}\text { The authorities should consider expanding the amount of data collected } \\
\text { through the supervisory reporting process. More complete information on } \\
\text { related party transactions should be required. To improve the level of } \\
\text { consolidated supervision, data on non-bank financial companies should be } \\
\text { collected from banks on a solo basis. }\end{array}$ \\
\hline $\begin{array}{l}\text { 22. Accounting and } \\
\text { disclosure }\end{array}$ & $\begin{array}{l}\text { Notwithstanding the high standards of professionalism and expertise } \\
\text { established in the auditing profession, it is recommended that the authorities } \\
\text { obtain the power to reject the appointment of an auditor by a bank. With this } \\
\text { power, the supervisors can ensure that all banks select auditors of the highest } \\
\text { quality that have been licensed by the governing agency, would not be } \\
\text { compromised by conflicts of interest, or would be objectionable for other } \\
\text { reasons. The rotation of external auditing firms could have the benefit of } \\
\text { creating some competition in the industry, as there are a minimal number of } \\
\text { firms providing these services at present. Consideration should be given to } \\
\text { having a formal meeting with the external auditor subsequent to the } \\
\text { completion of the audit to discuss at length the auditor's evaluation of risk } \\
\text { management practices and the internal control system. }\end{array}$ \\
\hline
\end{tabular}




\begin{tabular}{|l|l|}
\hline \multicolumn{1}{|c|}{$\begin{array}{c}\text { Reference } \\
\text { Principle }\end{array}$} & \multicolumn{1}{c|}{ Recommended Action } \\
\hline $\begin{array}{l}\text { 23. Corrective and } \\
\text { remedial powers of } \\
\text { supervisors }\end{array}$ & $\begin{array}{l}\text { The Banking Law should be amended to enable BOS to remove a member of } \\
\text { the supervisory board for the same or similar reasons for which a member of } \\
\text { the management board may be removed. Such powers exist in connection } \\
\text { with the remedial powers the supervisors have in improving the quality of the } \\
\text { management board. All impediments to BOS's powers to require corrective } \\
\text { measures relative to ensuring that a bank has adequate capital should be } \\
\text { removed from the law. The authority granted under the Banking Act relative to } \\
\text { the resolution of a problem bank needs to be revised and strengthened to } \\
\text { afford the Supervisor of Banks with the flexibility to apply an appropriate } \\
\text { strategy in the event intervention in a problem bank is warranted. The entire } \\
\text { existing regulatory structure, including special administration, liquidation and } \\
\text { bankruptcy needs to be revised and strengthened in this regard. }\end{array}$ \\
\hline $\begin{array}{l}\text { 24. Consolidated } \\
\text { supervision }\end{array}$ & $\begin{array}{l}\text { Enhancements to the program of consolidated supervision should be } \\
\text { considered. Among such enhancements is a greater supervisory attention to } \\
\text { the non-bank financial subsidiaries and monitoring of intercompany } \\
\text { transactions in mixed activity companies. With respect to the non-bank } \\
\text { financial companies, collecting supervisory information and including them in } \\
\text { the SREP process more fully would provide insights into the risks undertaken } \\
\text { by these institutions. In addition, greater focus on related party interests within } \\
\text { a banking group is warranted both in a banking group and a mixed activity } \\
\text { company. }\end{array}$ \\
\hline
\end{tabular}

\section{Authorities' response}

\section{Bank of Slovenia generally agrees with the key findings and recommendations} from the BCP Assessment. However, in the view of Bank of Slovenia, the assessed consequences of identified weaknesses in implementation of BCP in Slovenia are disproportionate to a certain extent. Even highly effective banking supervision could not prevent the consequences of the financial crisis facing the Slovenian banking sector and corporate sector. Additionally, Bank of Slovenia has reservations towards recommendations requiring regulatory or other activities in areas which are immaterial for Slovenian banks (e.g. requirement to collect data from non-bank financial companies on a solo-basis). As the principle of proportionality is one of the core principles in banking supervision, it should also be reflected in the recommendations.

\section{Bank of Slovenia has already prepared an action plan for the implementation of} recommendations to improve compliance with the BCP. Bank of Slovenia proposed to the Ministry of finance several amendments of the Banking Act, including provisions on: (i) legal protection of the Banking Supervision staff, (ii) Bank of Slovenia's authority to licence supervisory board members and the acquisition of non-financial institutions, (iii) broader Bank of Slovenia's powers to require a bank to increase its capital, while at the same time not allowing bank's shareholders to impede this procedure, and (iv) introduction of new resolution tools as the basis for the future resolution regime. Legislative power however 
lies with the Parliament which is empowered to endorse the above-mentioned amendments to the legal acts.

85. Bank of Slovenia is committed to implement the aforementioned action plan, also in cooperation with other relevant authorities, and will strive for an even more proactive and forward looking approach to banking supervision in the future.

Strengthening the financial condition of the banking system is a key priority of all Slovenian authorities at present. 